Article

\title{
Science \& Technology Agenda for Blue-Green Spaces Inspired by Citizen Science: Case for Rejuvenation of Powai Lake
}

\author{
Balakrishnan Lekshmi ${ }^{1}{ }^{(\mathbb{D}}$, Dipanjan Saha ${ }^{1}$, Rahul S. Sutar ${ }^{1}$, Richa Singh ${ }^{1}$, Shardul D. Prabhu ${ }^{1}{ }^{10}$, \\ Arundhati M. Kamat ${ }^{1}$ (D), Shruti Sharma ${ }^{1}$, Raghuvansh Saxena ${ }^{2}$, Steven Loiselle ${ }^{3,4}{ }^{(D)}$ and Shyam R. Asolekar ${ }^{1, *}$ (D) \\ 1 Environmental Science and Engineering Department, Indian Institute of Technology Bombay, \\ Mumbai 400076, India; b.lekshmi.nair@iitb.ac.in (B.L.); dipanjan645@gmail.com (D.S.); \\ atulrahul15@gmail.com (R.S.S.); richasingh2010@gmail.com (R.S.); shardul_prabhu@iitb.ac.in (S.D.P.); \\ arundhatik@iitb.ac.in (A.M.K.); shruti_sharma@iitb.ac.in (S.S.) \\ 2 Earthwatch Institute India Trust, Gurgaon 122002, India; rsaxena@earthwatch.org.in \\ 3 Earthwatch Europe, Mayfield House, 256 Banbury Road, Oxford OX2 7DE, UK; sloiselle@earthwatch.org.uk \\ 4 Department of Biotechnology, Chemistry and Pharmacy, University of Siena, \\ Consorzio Interuniversitario Nazionale per la Scienza e Tecnologia dei Materiali (INSTM), 53100 Siena, Italy \\ * Correspondence: asolekar@iitb.ac.in; Tel.: +91-22-2576-7867
}

check for

updates

Citation: Lekshmi, B.; Saha, D.; Sutar, R.S.; Singh, R.; Prabhu, S.D.; Kamat,

A.M.; Sharma, S.; Saxena, R.; Loiselle,

S.; Asolekar, S.R. Science \&

Technology Agenda for Blue-Green Spaces Inspired by Citizen Science: Case for Rejuvenation of Powai Lake. Sustainability 2021, 13, 10061. https:/ / doi.org/10.3390/su131810061

Academic Editor: Daniela Baldantoni

Received: 14 July 2021

Accepted: 3 September 2021

Published: 8 September 2021

Publisher's Note: MDPI stays neutral with regard to jurisdictional claims in published maps and institutional affiliations.

Copyright: (c) 2021 by the authors. Licensee MDPI, Basel, Switzerland. This article is an open access article distributed under the terms and conditions of the Creative Commons Attribution (CC BY) license (https:// creativecommons.org/licenses/by/ $4.0 /)$.
Abstract: Urban lakes play a major role in the socio-cultural and ecological sustainability of many cities, but are often under major development and pollution pressures. Urban decision makers are faced with a challenging task of identifying the causes of their decline and building plans for their conservation or rejuvenation. Powai Lake is a perfect example of an urban water body with historic, cultural, and ecological importance to the population of Metropolitan Mumbai, with local and regional authorities, including the Urban Development Department, Government of Maharashtra, working to identify methods for rejuvenating the Lake. In this context, characterization of pollution dynamics, hotspots, and extent is fundamental to the development of management plans and appropriate technologies for the remediation and rejuvenation of Powai Lake-the long-term goal of the present study. A two-year monitoring program at eight sampling locations on the Lake's periphery, with the engagement of citizen scientists along with environmental researchers, revealed clear seasonal and spatial dynamics that allowed for the identification of pollution drivers and the development of a three-phase rejuvenation plan. The plan represents a novel and holistic approach that recognizes Powai Lake as a complex system with multiple drivers, and aims at ecological balance and sustainable delivery of ecosystem services.

Keywords: Powai Lake; lake rejuvenation; citizen science; nature-based solution; natural treatment system; constructed wetland; water quality index; blue-green balance; capacity building

\section{Introduction}

Major factors that lead to the degradation of surface water bodies are often related to progressive urbanization and the resulting imbalance between blue-green spaces within urban ecosystems. In the case of India, disposal of untreated sewage and partially treated industrial effluents into lakes, rivers, and coastal ecosystems have outpaced the pollution control systems instituted by urban local bodies and communities. This has resulted in conditions of increased turbidity, algal blooms, eutrophication, and siltation in most urban water bodies [1-3].

Given the vital role that urban lakes play in flood control, pollution mitigation, landscaping, and recreation, the Ministry of Housing and Urban Affairs, Government of India (GoI), has intervened with mission mode projects, including Jal Shakti Abhiyan, Smart Cities Mission, and Atal Mission for Rejuvenation and Urban Transformation [4]. These efforts are aligned with the UN Sustainable Development Goals SDG 6, SDG 11, SDG 14, and SDG 17 , and demonstrate India's commitment to securing water resources and building resilient cities through multi-stakeholder partnerships [5]. Asolekar et al. [1], Arceivala and 
Asolekar [6], Kumar et al. [7], and Hutchins et al. [8] have demonstrated the significance of developing new eco-niches by employing nature-based solutions $(\mathrm{NbSs})$ e.g., natural treatment systems (NTSs) like constructed wetlands (CWs), polishing ponds, waste stabilization ponds, etc., and thereby revitalizing the blue-green spaces in urban ecosystems.

There are numerous examples of ecological, environmental, and social transformation actions implemented in India using innovations in treatment and reuse of wastewaters, including (a) rejuvenation of Mansagar Lake [1], (b) restoration of Kaikondrahalli Lake [9,10], (c) development of a recreational garden and female empowerment in Mhaswad Town [11,12], and (d) expansion of green spaces at a religious institution for the benefits of pilgrims in the town of Katel [13]. The transformation of Mansagar Lake in Jaipur through a public-private partnership and restoration of Kaikondrahalli Lake in Bengaluru through multi-stakeholder, socially inclusive development were cited by the NITI Aayog, GoI, and UNDP [14]. These success stories were highlighted as sustainable solutions not only for aesthetics and recreation but also for the source of revenue.

In India, lakes provide numerous ecosystem services to urban clusters if appropriately managed. Lake rejuvenation is often hindered by knowledge gaps related to pollution dynamics and pollution hotspots [1,3]. Systematic water quality monitoring and the use of aggregated water quality indices can be used to create pollution maps and identify tipping points. Various water quality indices (WQIs) have been in use to assess the overall status of a water resource with complex pollution dynamics, by combining the pollution potential of the individual parameters [15].

In recent years, citizen science has been shown to be a useful and robust scientific data collection technique $[16,17]$ as well as supporting bottom-up environmental conservation by taking the concerns of citizens into account [18]. Further, it enhances the local communities' awareness of environmental concerns and thereby reinforces their willingness to engage in environmental conservation [19-21]. Scientists have recognized the local communities' involvement in data collection in several sectors including population dynamics of animal species [22-24], marine debris abundance in sanctuaries [25], assessment of soil characteristics in urban green spaces [26], and development of green infrastructure and urban green spaces [27]. Citizen science has been successfully applied for the creation of data sets and monitoring of water quality in river catchments [28], streams and lakes [29,30], and wetlands [31].

Powai Lake is a cornerstone ecosystem in the megacity of Mumbai with rich biodiversity [32-34], around which the suburb of Powai has rapidly developed into a residential and commercial hub in the last 3-4 decades. The developed communities of Powai are connected to a sewerage network. However, local informal settlements are not connected to a sewerage network with some portion of their wastewaters running into the Lake [35]. Recent studies indicate that poor water quality (including levels of organics and nutrients) in Powai Lake are associated with disposal of sewage and urban runoff as well as episodic pollution on account of idol immersion and religious rituals [1,36-41]. Surya et al. [42], in their study on fish ecology, linked the ecological degradation of the Lake to pollution inflows. These monitoring studies had a limited number of sampling points and were conducted over a short span of time.

The degradation of lakes, rivers, creeks, and ocean-fronts in Mumbai is likely to have large-scale impacts on the City's green spaces. For example, the prime and favored residential and institutional locations in Powai happen to be in the vicinity of the contiguous blue-green ecosystem encompassing Powai Lake, Aarey woods, and Sanjay Gandhi National Park. It is not surprising that the youth in Mumbai and the citizens of Powai area joined hands with non-governmental organizations (NGOs) to oppose construction of a rail car shed near these remaining green spaces, resulting in their conservation [43]. The continued growing attention to preserving and restoring these green spaces is key to maintaining functioning urban ecosystems.

It is increasingly evident that blue and green ecosystems are mutually dependent and often quite delicate. The selection of technological interventions for lake rejuvena- 
tion necessitates robust and continuous information on water quality and wastewater discharges. The main objective addressed in the present study was to systematically assess pollution hotspots and the temporal drivers of water quality in Powai Lake. Water quality indices were used to describe the variations in the state of the environment, as well as to communicate effectively to the community and decision makers. This study incorporated citizen science to complement data collection by the research team as well as to engage the local population as a bridge between the technical team and the civic administration. Finally, this study discusses the rejuvenation plan for Powai Lake based on the insights of professional environmental scientists, the civic administration, and the agenda articulated by the involvement of citizen scientists.

\section{Methods}

\subsection{Study Area}

Powai Lake $\left(19^{\circ} 7^{\prime} 41.38^{\prime \prime} \mathrm{N}, 72^{\circ} 54^{\prime} 18.61^{\prime \prime} \mathrm{E}\right)$ is situated in metropolitan Mumbai and is one of its most beautiful landscapes (Figure 1). The Lake came into existence in 1891, when a $10 \mathrm{~m}$ tall barrage was constructed between two hillocks across Powai Basin to harvest rainwater for drinking purposes. The water was found to be unfit for drinking due to its indiscriminate use for domestic purposes by local people and also due to addition of sewage. However, a rich assortment of flora and fauna grew around Powai Lake including 50 species of birds and other aquatic species [44]. It was leased to the Maharashtra State Angling Association and is a primary angling spot in Mumbai and home to many Indian carp fish families [45].

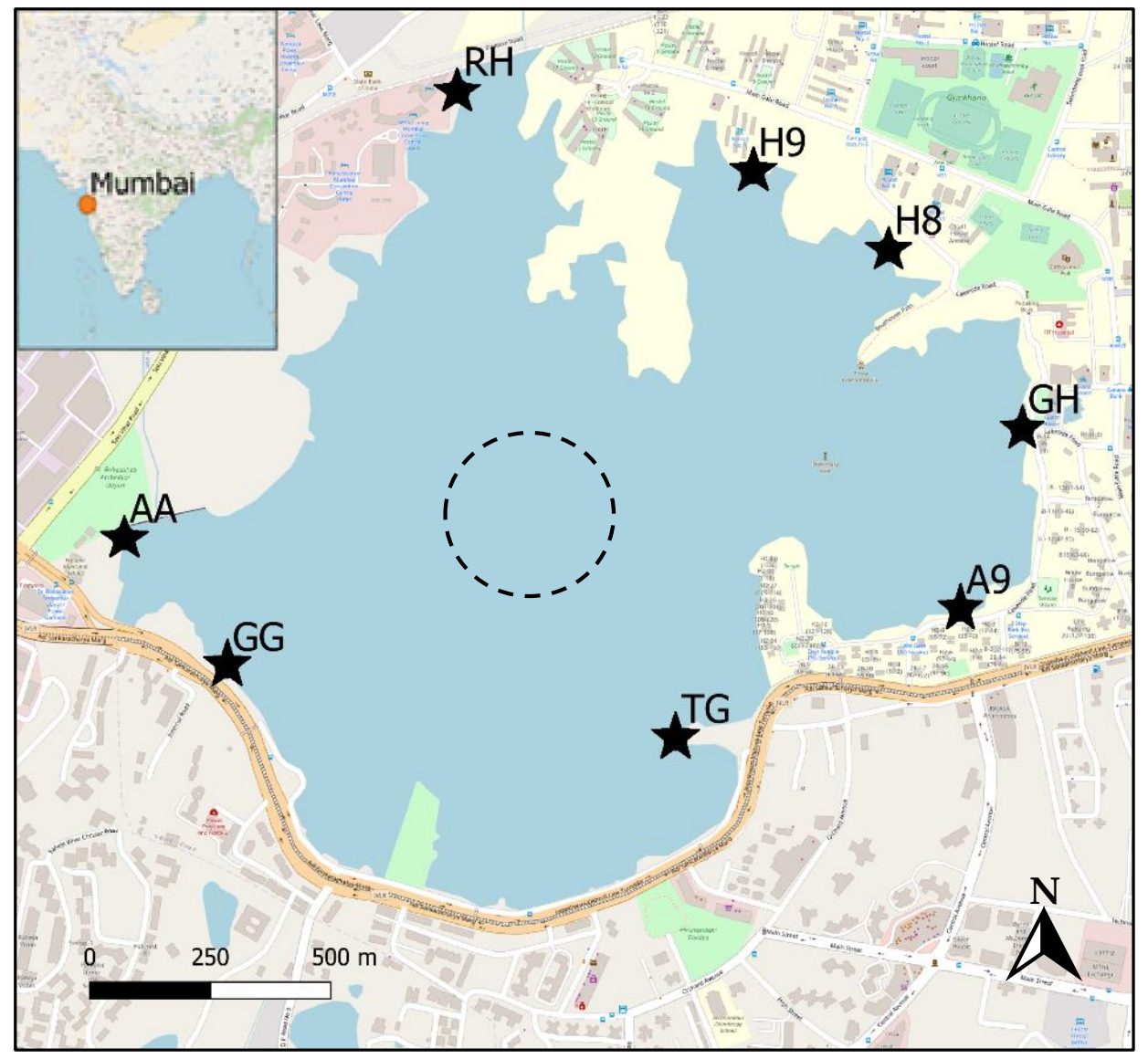

Figure 1. The study area in this research is the Powai Lake $\left(19^{\circ} 7^{\prime} 41.38^{\prime \prime} \mathrm{N}, 72^{\circ} 54^{\prime} 18.61^{\prime \prime} \mathrm{E}\right)$ in the City of Mumbai, State of Maharashtra, India. The eight designated sampling stations are indicated by black stars on the Lake periphery and the approximate location for occasional sampling in the central zone of the Lake is indicated by the black dotted circle. 
Powai Lake has approximately $3 \mathrm{~m}$ depth along the periphery and $10 \mathrm{~m}$ in the middle [37]. Located at an altitude of $58.5 \mathrm{~m}$ above sea level, the Lake has an extension of $2.2 \mathrm{~km}^{2}$ with a catchment area of $6.61 \mathrm{~km}^{2}$. It is surrounded by IIT, NITIE, Vihar Lake, Powai Garden, and residential as well as commercial complexes. The rapid urbanization of the surrounding areas has led to siltation of the lake, encroachment by builders, disposal of sewage, and deforestation in the surrounding regions [35].

\subsection{Recruitment and Training of Citizen Scientists and Their Engagement in Data Collection}

In the present study, multiple training events (6) were organized for citizen scientists in relation to the HSBC sustainability training programs (STPs) and conducted by Earthwatch India in coordination with IITB Research Scientists. In each event, new community and HSBC volunteers were trained to become citizen scientists and engaged in water quality monitoring for Powai Lake. These citizen scientists were residents of Mumbai and were highly motivated and encouraged to participate in the monitoring activities for Powai Lake.

In each training event, citizen scientists were introduced to the significance of water quality, and the need for rejuvenation of the lake and ecosystem through successful case studies $[1,11-13]$. This was followed by a one-hour brainstorming session that addressed queries of citizen scientists relating to the science behind water quality monitoring, treatment of wastewater using NTSs, economic and social implications of lake rejuvenation, etc. Training on monitoring methods, parameters, and monitoring instruments required two hours.

It was envisaged that participants will benefit from increased scientific knowledge, empowerment related to potential solutions, awareness of the city's environmental problems, and satisfaction by being connected to nature and people. In each STP, citizen scientists were also given hands-on experience at the pilot-scale constructed wetland, which treats domestic wastewater, at the IITB research station. Research scientists and citizen scientists actively discussed its potential for treating and reusing municipal wastewater and the significance of such an intervention in a given community towards the implementation of concepts of the circular economy. Subsequently, volunteers dispersed to sampling stations for collection of water quality data. Three sampling stations were designated for citizen scientists for sample collection and analysis of water quality. Research scientists worked closely with the citizen scientists and ensured that water quality monitoring was carried out following determined measurement and quality control protocols.

\subsection{Organization of Water Quality Monitoring and Data Analyses}

Monthly water quality monitoring by citizen scientists and professional scientists was conducted between April 2018 and March 2020. An initial reconnaissance survey was conducted along the entire periphery of Powai Lake, and by combining the information on the pollution potential of land use along the periphery, the eight sampling locations were designated (Table 1, Figure 1). Land use activities identified were fishing, cattle rearing, and religious events. Potential wastewater discharges were identified and geolocated. The selection of sampling locations was also conditioned by their accessibility and safety of the citizen scientists and based on experience of the Powai Lake Rejuvenation Committee. As the Lake is a habitat for reptiles and crocodiles [46], sampling could not be conducted at the center of the Lake. However, given these safety concerns, efforts were made to collect samples occasionally with the help of local fishermen. Although the exact GPS locations of those sampling spots could not be recorded, the approximate zone can be seen as the black dotted circle in Figure 1. In all, four sampling campaigns were conducted during the study period and two nearby locations were chosen for collecting samples in the central zone of the Lake during each campaign. 
Table 1. The details of eight designated stations for sampling campaigns for the study in Powai Lake.

\begin{tabular}{cccc}
\hline Sr. No. & Sites & Coordinates & Description \\
\hline \multirow{2}{*}{1} & AA & $19^{\circ} 7^{\prime} 35.37^{\prime \prime} \mathrm{N}$, & Observed angling activities \\
& & $72^{\circ} 53^{\prime} 45.06^{\prime \prime} \mathrm{E}$ & \\
& & $19^{\circ} 7^{\prime} 26.78^{\prime \prime} \mathrm{N}$, & Idol immersion and occasional fishing noticed \\
& GG & $72^{\circ} 53^{\prime} 52.47^{\prime \prime} \mathrm{E}$ & \\
& & $19^{\circ} 7^{\prime} 22.58^{\prime \prime} \mathrm{N}$, & Recreational spot and idol immersion observed \\
3 & TG & $72^{\circ} 54^{\prime} 24.08^{\prime \prime} \mathrm{E}$ & \\
& & $19^{\circ} 7^{\prime} 31.25^{\prime \prime} \mathrm{N}$, & Box culvert for stormwater drains \\
4 & A9 & $72^{\circ} 54^{\prime} 44.53^{\prime \prime} \mathrm{E}$ & \\
& & $19^{\circ} 7^{\prime} 43.48^{\prime \prime} \mathrm{N}$, & Idol immersion and recreation were noticed \\
5 & GH & $72^{\circ} 54^{\prime} 48.77^{\prime \prime} \mathrm{E}$ & \\
& & $19^{\circ} 7^{\prime} 56.56^{\prime \prime} \mathrm{N}$, & Stormwater drain \\
6 & $\mathrm{H} 8$ & $72^{\circ} 54^{\prime} 40.21^{\prime \prime} \mathrm{E}$ & \\
& & $19^{\circ} 8^{\prime} 1.80^{\prime \prime} \mathrm{N}$, & Site receiving runoff from Vihar Lake water \\
7 & $\mathrm{H} 9$ & $72^{\circ} 54^{\prime} 30.27^{\prime \prime} \mathrm{E}$ & \\
& & $19^{\circ} 8^{\prime} 6.75^{\prime \prime} \mathrm{N}$, & Stormwater drain \\
& & $72^{\circ} 54^{\prime} 7.96^{\prime \prime} \mathrm{E}$ & \\
& $\mathrm{RH}$ & &
\end{tabular}

As per the CPCB's classification of surface waters [47], 'Class A' water quality is typically considered the most suitable water resource for feeding the water works (responsible for production of drinking water by treating the surface water). Vihar Lake has been a Class A resource and feeds into the water works for the mega-city of Mumbai. Therefore, H9 station receiving water from Vihar Lake was taken as a reference station to study the variations in pollution in Powai Lake.

Fifteen sampling campaigns were conducted between April 2018 and March 2020 by the IITB Research Team and 6 sampling campaigns were by citizen scientists. Citizen scientists collected water samples from three predetermined sampling locations (GG, TG, and $\mathrm{H} 9$ ) and monitored water quality parameters temperature, $\mathrm{pH}$, total dissolved solids (TDS), and dissolved oxygen (DO) using portable real-time instruments. Samples were transported at $4{ }^{\circ} \mathrm{C}$ to a research laboratory for further analyses following the Standard Methods for the Examination of Water and Wastewater.

A portable HACH USA (HQ40d) multi-meter was used for in situ analyses of $\mathrm{pH}$, temperature, TDS, DO, ammonia nitrogen $\left(\mathrm{NH}_{3}-\mathrm{N}\right)$, and nitrate nitrogen $\left(\mathrm{NO}_{3}-\mathrm{N}\right)$. Further, chemical oxygen demand (COD) was determined using the closed reflux method, and biochemical oxygen demand $\left(\mathrm{BOD}_{5}\right)$ was measured after incubation for five days at 20 ${ }^{\circ} \mathrm{C}$. For total kjeldahl nitrogen (TKN) estimation, digestion and distillation were carried out using a block digestion unit and a semi-automatic steam distillation unit, respectively. The ammonium molybdate spectrophotometric method was used to determine total phosphorous (TP). Fecal coliforms (FC) were estimated by membrane filtration followed by incubation at $44.5^{\circ} \mathrm{C}$ [48].

For the assessment of seasonal variations in each sampling location, the 21 sampling events were grouped in seasons, namely monsoon (June to September), post-monsoon (October to January), and summer (February to May). In each season, eight observations for each parameter were recorded for each station. Pollutant concentrations recorded at the Lake's center were not numerous enough to establish seasonal variations, hence they were represented with mean values and standard deviation (SD). Data were analyzed using Student's $t$-test ( $0.05 \%$ level of significance) for evaluating differences in seasonal changes and spatial variations. All statistical analyses were carried in Microsoft Excel (2016). QGIS 3.4.3 was used to create maps of the study area and the water quality index.

\subsection{Water Quality Index}

The National Sanitation Foundation Water Quality Index (WQI) $[49,50]$ was used to classify changes in lake water quality. This widely used index is based on nine parameters: $\mathrm{DO}$, fecal coliform ( $\mathrm{CFU}), \mathrm{pH}, \mathrm{BOD}_{5}$, temperature, total phosphate, nitrate, turbidity, and 
total solids (TS). The provision to add or eliminate any parameter as and when required is also allowed considering the significance of monitored water quality. In the present study, WQI was calculated based on the eight parameters for twenty-one sampling months. As an alternative to TS, TDS was used in the calculations. The results of WQI had no considerable variations when non-original parameter TDS was used in place of TS [51]. The WQI is calculated based on Equation (1) [50]:

$$
\text { NSFWQI }=\frac{\sum_{i=1}^{N} W_{i} Q_{i}}{\sum_{i=1}^{N} W_{i}},
$$

where $Q_{i}$ is the sub-index and $W_{i}$ is the weight coefficient for $i$ th water quality parameter. The number of water quality parameters is represented as $N$, and the quality is reported as per the values shown in Table 2 . To convert the water quality parameters from concentration metrics to new units of pollution level or sub-indices, a set of sub-index rating curves was used [52]. This single index of pollution was calculated and expressed on a normalized pollution scale, and the overall WQI was then reported as the weighted geometrical average of individual parameters. Thus, weight coefficients of these parameters were 0.17 (DO), 0.16 (FC), $0.11\left(\mathrm{BOD}_{5}\right), 0.11(\mathrm{pH}), 0.1\left(\mathrm{NO}_{3} \mathrm{~N}\right), 0.1$ (temp), $0.1(\mathrm{TP})$, and 0.07 (TDS).

Table 2. Interpretation of WQI values as reported by Brown et al. [50].

\begin{tabular}{cc}
\hline NSFWQI & Description of Quality \\
\hline $91-100$ & Excellent \\
$71-90$ & Good \\
$51-70$ & Medium \\
$26-50$ & Bad \\
$0-25$ & Very Bad \\
\hline
\end{tabular}

\subsection{Development of a Rejuvenation Plan for Powai Lake}

The National Environment Policy (NEP) [53] recommends that action plans for lake restoration integrate conservation strategies along with poverty alleviation, livelihood improvement, and eco-tourism. Present and future generations should receive ecological, social, and economic benefits of a well-managed lake [54], and therefore strategies should be based on multi-stakeholder partnerships and regulatory enforcement $[39,55]$. Successful lake rejuvenation case studies in India that provided local communities with aesthetic and recreational spaces, and a source of revenue, are very limited. One such example was the Mansagar Lake rejuvenation in the City of Jaipur, State of Rajasthan. Environmental conservation, heritage restoration, and business promotion were all addressed while executing the restoration plan in Mansagar Lake. A successful public-private partnership model for rejuvenation through $\mathrm{NbS}$ was completed in eight years, and the lake returned to full health $[1,14]$. Similarly, a multi-stakeholder socially inclusive restoration of Kaikondrahalli Lake in the City of Bengaluru, State of Karnataka, was carried through the local administrative body, with community maintenance employed by an NGO and funding for maintenance provided by another NGO, along with the Revenue Department providing administrative and legal support $[9,10,14]$.

In the past two decades, several attempts have been made to reduce pollution loads to the Powai Lake by the municipality as well as the Government of Maharashtra and Ministry of Environment, Forest and Climate Change (MoEF\&CC), GoI, New Delhi, India. Their efforts were limited to "direct interventions in Powai Lake". While these efforts had some success, the underlying problem remained unaddressed. The limitations of these non-integrated approaches were addressed while developing the present rejuvenation plan, which was prepared from scientific evidence gathered from water quality monitoring, a growing experience on lake rejuvenation, and also through the engagement of stakeholders. Along with citizen scientists' participation in water quality monitoring, capacity building workshops and round-table conferences were conducted to provide a shared knowledge 
of the concepts in urban and rural ecological restoration of blue-green spaces through water reuse and community engagement. Stakeholders included regulatory agencies, NGOs, industry, municipality, and faculty members, graduate, post-graduate, and doctoral students from educational institutions in India especially Mumbai, Nepal, Uganda, and three universities from the European Union; namely, Norwegian University of Science and Technology from Ålesund, Instituto Superior Técnico from Lisbon, and TU Delft from The Netherlands [56]. The action plan for Powai Lake rejuvenation was prepared employing inputs from panel discussions with a wide range of local and non-local stakeholders.

\section{Results and Discussion}

\subsection{Data Collection}

A total of 544 data points were collected by citizen scientists in the course of six sampling campaigns during few summer and post-monsoon months (Table 3). Data collected by citizen scientists in summer and post-monsoon months were significantly correlated with research scientists' data in the months in corresponding seasons.

Table 3. Details of water sampling campaigns at Powai Lake by the citizen scientists in collaboration with IITB research scientists.

\begin{tabular}{|c|c|c|c|c|c|}
\hline Sr. No. & $\begin{array}{l}\text { Dates of Sampling } \\
\text { Campaigns }\end{array}$ & $\begin{array}{l}\text { Sampling } \\
\text { Stations }\end{array}$ & Sample Size & $\begin{array}{l}\text { Maximum No. of } \\
\text { Parameters } \\
\text { Monitored }\end{array}$ & $\begin{array}{c}\text { Total Data Points } \\
\text { Collected }\end{array}$ \\
\hline 1 & 12-13 April 2018 & 3 (GG, TG, H9) & 27 & 4 & 140 \\
\hline 2 & 11-12 October 2018 & $3(\mathrm{GG}, \mathrm{TG}, \mathrm{H} 9)$ & 42 & 4 & 168 \\
\hline 3 & 21-22 February 2019 & $3(\mathrm{GG}, \mathrm{TG}, \mathrm{H} 9)$ & 29 & 4 & 116 \\
\hline 4 & 4-5 April 2019 & $1(\mathrm{H} 9)$ & 10 & 4 & 40 \\
\hline 5 & 7-8 November 2019 & 1 (H9) & 10 & 4 & 40 \\
\hline \multirow[t]{2}{*}{6} & 28-29 November 2019 & 1 (H9) & 10 & 4 & 40 \\
\hline & & & & Total Data Sets & 544 \\
\hline
\end{tabular}

Water quality monitoring of Powai Lake conducted by IITB Research Scientists expanded and validated the monitoring conducted by citizen scientists (Table 4).

Table 4. Details of twenty-one sampling campaigns at Powai Lake conducted by the IITB research scientists.

\begin{tabular}{cccccc}
\hline $\begin{array}{c}\text { Sampling } \\
\text { Location }\end{array}$ & $\begin{array}{c}\text { No. of. Months } \\
\text { Sampled }\end{array}$ & $\begin{array}{c}\text { No. of. Sampling } \\
\text { Stations }\end{array}$ & $\begin{array}{c}\text { Sample Size in } \\
\text { One Campaign }\end{array}$ & $\begin{array}{c}\text { Total Samples } \\
\text { Collected }\end{array}$ & $\begin{array}{c}\text { Maximum No. of } \\
\text { Parameters } \\
\text { Monitored }\end{array}$ \\
\hline $\begin{array}{c}\text { Lake Periphery } \\
\text { Lake Centre }\end{array}$ & 21 & 8 & 8 & 168 & 11 \\
\hline
\end{tabular}

Capacity building and awareness creation was successfully carried out during citizen scientist training through the classroom interaction and walk-the-talk during the sampling campaigns. The interaction helped cultivate the 'environmental conscience' of the participants, a key benefit from the incorporation of citizen science in environmental monitoring [18,21]. The questions and comments of the citizen scientists indicated that they recognized the potential importance of NTSs for lake rejuvenation. The incorporation of citizen science facilitated not only scientific knowledge gain and empowerment for local communities, but also helped in setting the scientific agenda for technological intervention for the Powai Lake rejuvenation plan.

\section{2. $D O, p H$, and TDS}

Lake temperature recorded in the present study ranged between $26^{\circ} \mathrm{C}$ and $31^{\circ} \mathrm{C}$, with no significant spatial or temporal variations. Drastic temperature variations that could affect aquatic life [57] were not observed in the study. These observations were comparable 
with the values reported by Usman et al. [40] and Kadu et al. [58]. It is also to be noted that one of the previous studies reported water temperature values in the range of $20^{\circ} \mathrm{C}$ to $34{ }^{\circ} \mathrm{C}$ in Powai Lake [39]. This disparity could be due to the difference in the location of the sampling sites, depths of sampling, and the temperatures of incoming wastewaters, as well as the differences in sampling periods of the studies as compared to this study. Water temperature was not monitored in the center of the Lake.

$\mathrm{pH}$ varied between 6.97 and 8.07, (Figure 2), with no significant spatio-temporal variations. $\mathrm{pH}$ values were on the higher side of the permissible tolerable alkaline $\mathrm{pH}$ $(<8)$, especially during the summer season at sampling stations GG, TG, GH, and H9. Usman et al. [40] reported a similar range of $\mathrm{pH}$ values in Powai Lake during a one-year study period between 2016 and 2017. A prime factor for the high pH levels in Powai Lake might be the increased assimilation of carbonates and bicarbonates triggered by immersion of idols year-after-year in large numbers in Powai Lake. These changes in $\mathrm{pH}$ levels can affect the aquatic flora and fauna in the Lake.

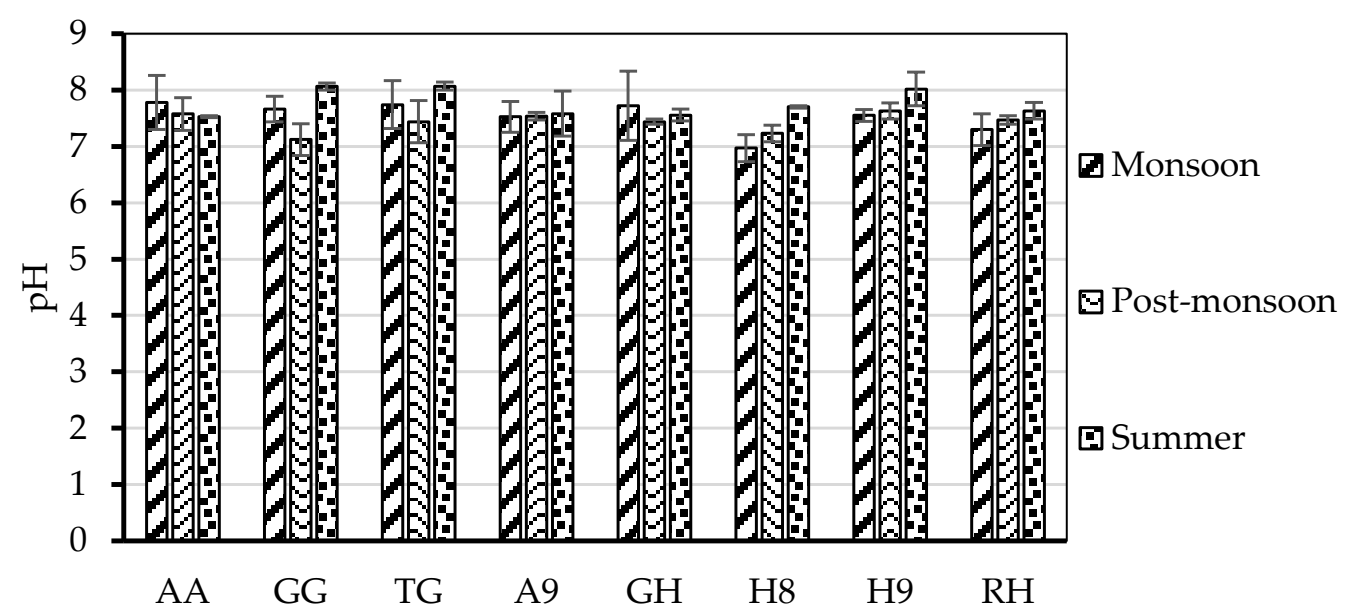

Figure 2. Seasonal variation of $\mathrm{pH}$ in Powai Lake represented as mean at different sampling locations. Error bars represent standard deviation.

The average $\mathrm{DO}$ concentrations at $\mathrm{A} 9, \mathrm{RH}, \mathrm{H} 8$, and $\mathrm{GH}$ stations were below $4 \mathrm{mg} / \mathrm{L}$, which is the minimum required DO concentration for healthy aquatic life in freshwater [59] (Figure 3). The lowest DO ( $<2 \mathrm{mg} / \mathrm{L}$ ) was observed in sampling stations A9 and RH. All seasons evidenced similar $\mathrm{DO}$ concentrations at $\mathrm{GH}$ and $\mathrm{H} 8$, implying unvarying pollution. The DO concentrations at AA, GG, TG, and A9 stations exhibited significant variation between monsoon and post-monsoon seasons $(p<0.05)$, with lower concentrations in post-monsoon. Similarly, significant differences in the DO concentrations were observed between summer and monsoon seasons at sampling stations GG, TG, AA, RH, and A9 with the lowest DO concentrations during the summer $(p<0.05)$. The decrease in DO concentrations from monsoon to summer season could be due to the pollution loading, together with excessive hyacinth growth with eutrophic conditions. 


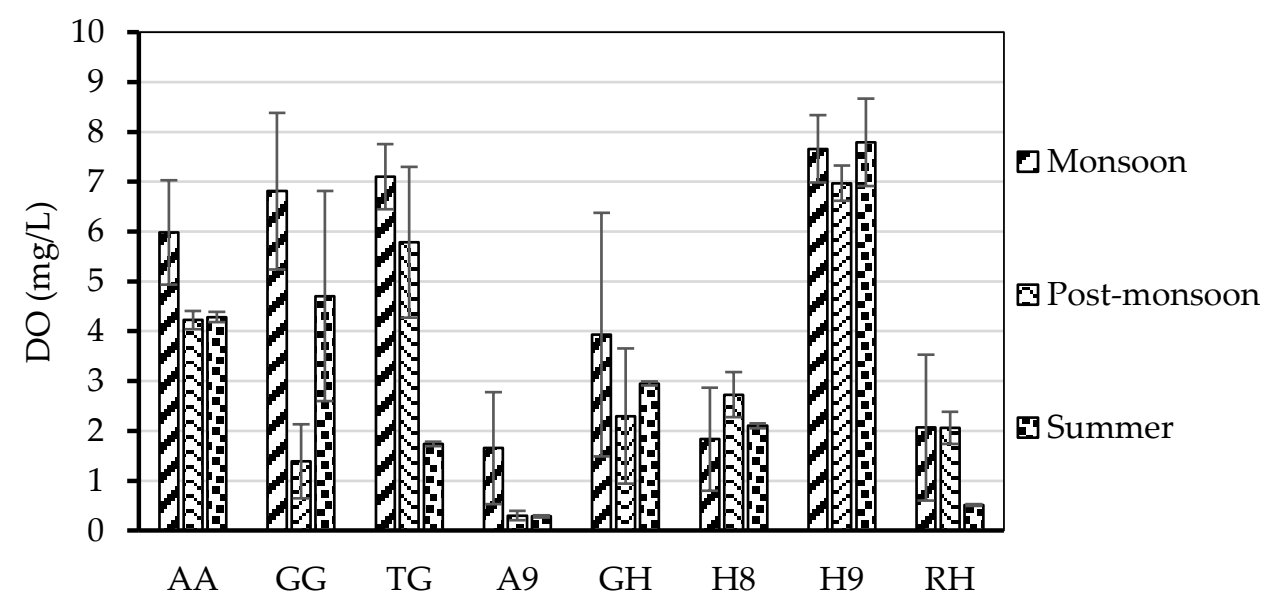

Figure 3. Seasonal variation of DO in Powai Lake represented as mean at different sampling locations. Error bars represent standard deviation.

Unlike other sites, no significant seasonal variation in DO concentrations was observed at $\mathrm{H} 9$ as there was no pollution loading at the site. The comparison of DO levels reported by Ratheesh et al. [38] (3.58-7.19 mg/L), Salaskar and Muley [39] (3.9-6.3 mg/L), and Surya et al. [42] (2.8-8 mg/L) with the DO levels in the present study clearly suggests that the DO concentrations have drastically altered in recent years.

From the littoral and limnetic zones monitored in Powai Lake, it was observed that the mean TDS concentration in the Lake was, respectively, $223 \pm 110 \mathrm{mg} / \mathrm{L}(n=143)$ and $157 \pm 10(n=16)$, with significant differences $(p<0.01)$ between the two zones. These high levels of TDS can interfere with the mineral content of water and induce high osmotic pressure, which can harm aquatic species [60]. As depicted in Figure 4, the highest TDS concentrations ( $>500 \mathrm{mg} / \mathrm{L}$ ) at more than desirable limits [61], were observed at A9 and RH sampling stations during all seasons, an indication of the continually higher pollution inflows through these sites. In addition, stations AA, GG, and GH had significantly $(p<0.05)$ high TDS concentrations during the summer months. From the present study, it is evident that in Powai Lake there was an increase in TDS through 2018-2020 when compared to concentrations of 50-220 mg/L, $185-238 \mathrm{mg} / \mathrm{L}$, and $257 \pm 116 \mathrm{mg} / \mathrm{L}$ reported, respectively, by Usman et al. [40] in 2017-2018, Kadu et al. [58] in 2014-2015, and Salaskar and Muley [39] in 2010-2012.

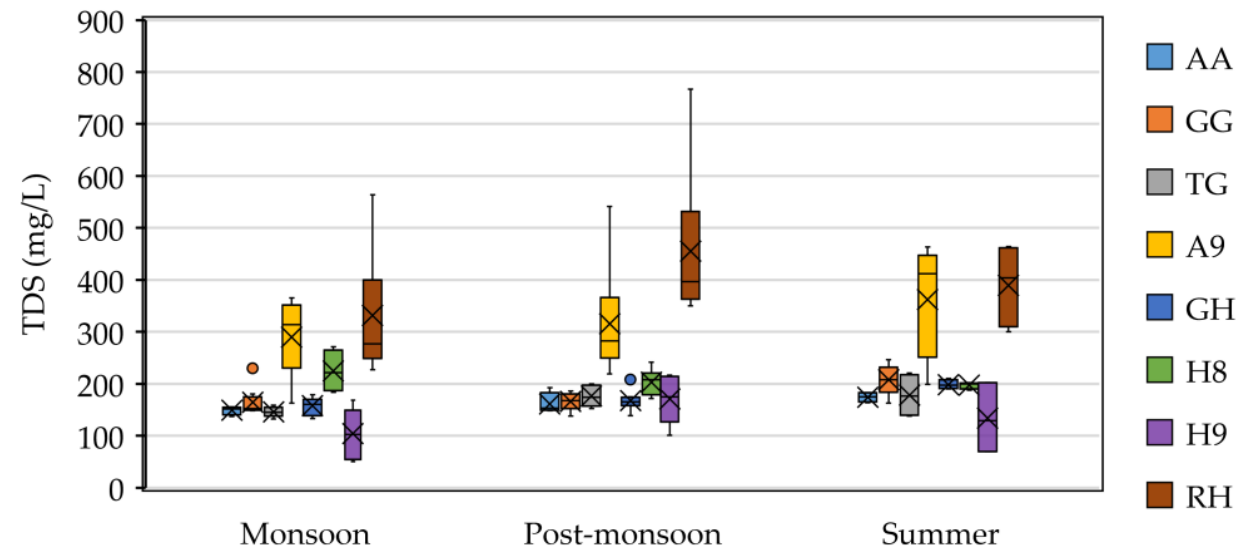

Figure 4. Seasonal variation of TDS in Powai Lake at different sampling locations shown as box plots. The top and bottom of the box indicate the 75th and 25th percentiles, line within the box represents median, cross represents mean, range bar represents the maximum and minimum values, and dots represent the outliers. 


\subsection{Organic Pollution}

In the course of this study, at least one incidence of high COD ( $>50 \mathrm{mg} / \mathrm{L})$ was observed in all the stations, except for $\mathrm{H} 9$, with the highest concentrations observed during summer and post-monsoon months. Figure 5 shows the seasonal variation in COD at the eight sampling locations in Powai Lake. COD concentrations were significantly higher during the post-monsoon season compared to the monsoon season at sampling stations GG, TG, and A9 $(p<0.05)$. However, no significant variations in COD concentrations were observed between post-monsoon and summer seasons at these stations, implying a similar pollution load. These observations also confirm that sources of pollution at these sites were more anthropogenic in nature.

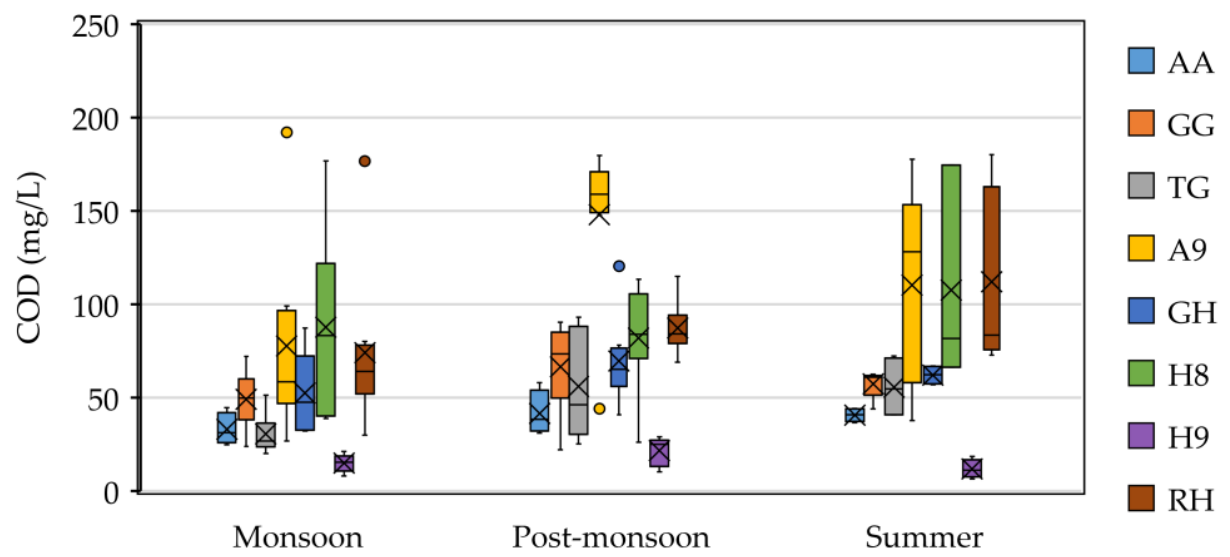

Figure 5. Seasonal variation of COD in Powai Lake at different sampling locations shown as box plots. The top and bottom of the box indicate the 75th and 25th percentiles, line within the box represents median, cross represents mean, range bar represents the maximum and minimum values, and dots represent the outliers.

The RH station had the highest COD (140-180 mg/L) in two sampling campaigns. However, at $\mathrm{RH}$, temporal variations were not markedly different as compared to other stations (AA, GH, and $\mathrm{H} 8$ ) receiving major pollution loads. The $\mathrm{H} 9$ station had the highest COD in the post-monsoon months; significant COD variations were also observed between monsoon and post-monsoon $(p<0.05)$ as well as post-monsoon and summer $(p<0.05)$ months. COD in the limnetic zone of $6.3-28.8 \mathrm{mg} / \mathrm{L}$ (mean $16.1 \pm 6.3 ; n=16$ ) was significantly different compared to the periphery $(p<0.05)$.

Bhateria and Jain [62] reported that natural sources like precipitation can bring nutrients, organic loading, and base-metal cations into the lake. There is runoff and erosion during monsoon season and subsequently these inputs were evident post-monsoon with increased COD at the H9 site. The Indian Meteorological Department reported that Mumbai City received $2239 \mathrm{~mm}$ and $3475 \mathrm{~mm}$ rainfall during 2018 and 2019, respectively [63]. The decreased trend in pollution during monsoon may be attributed to the dilution of lake water receiving elevated precipitation. Compared to previous studies [39,40,58], COD values in the present study were the highest $(>150 \mathrm{mg} / \mathrm{L})$ observations in past six years.

Temporal $\mathrm{BOD}_{5}$ differences were observed to follow a similar trend as that of $\mathrm{COD}$ (Figure 6). $\mathrm{BOD}_{5}$ concentrations were much higher than the limits $(<3 \mathrm{mg} / \mathrm{L})$ recommended by the ISI Standard [61] for the intended use of the water resource. During the study, at least one incidence of very high $\mathrm{BOD}_{5}(>20 \mathrm{mg} / \mathrm{L}$ ) was observed at all stations, except for $\mathrm{H} 9$, with the highest concentrations observed during summer and post-monsoon months. Similar to the COD trend, stations A9, H8, and RH had the highest $\mathrm{BOD}_{5}(>60 \mathrm{mg} / \mathrm{L})$, indicating the presence of discharges of partially treated domestic wastewaters to the Lake. $\mathrm{BOD}_{5}$ values at the center of the Lake were $3-13 \mathrm{mg} / \mathrm{L}$ (mean $8.1 \pm 3.1 ; n=16$ ) significantly different from the periphery $(p<0.05)$. Compared to the previous studies in the limnetic zones [38-40,58] and littoral zone [58] of Powai Lake, a clear increase in $\mathrm{BOD}_{5}$ was observed, particularly in the littoral zone. 


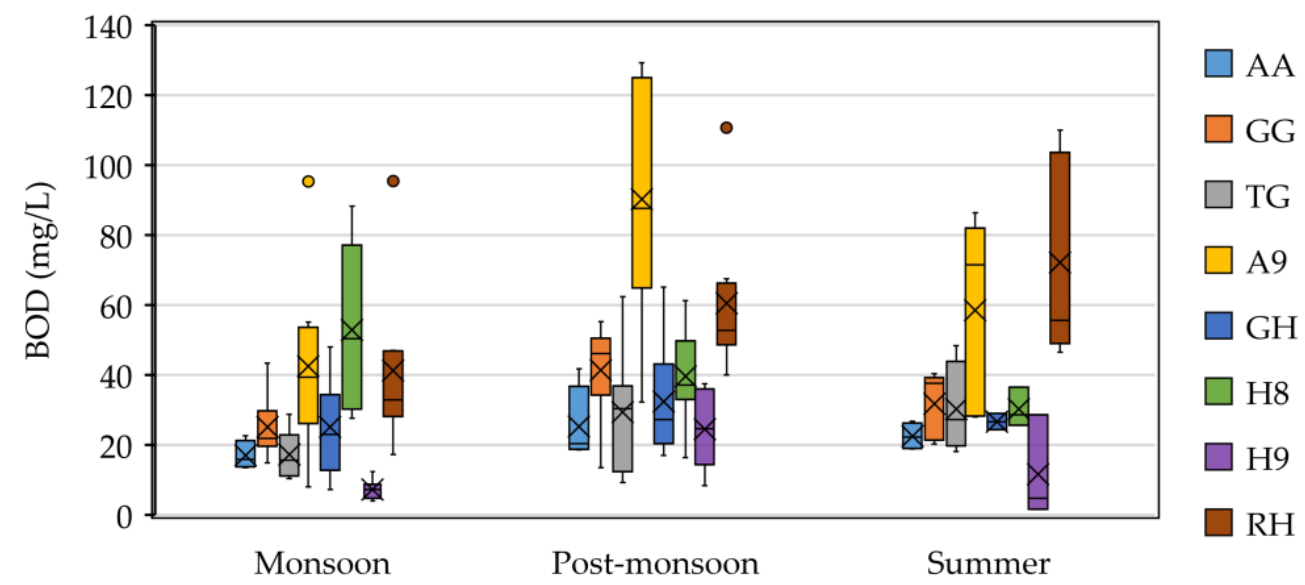

Figure 6. Seasonal variation of $\mathrm{BOD}_{5}$ in Powai Lake at different sampling locations shown as box plots. The top and bottom of the box indicate the 75th and 25th percentiles, line within the box represents median, cross represents mean, range bar represents the maximum and minimum values, and dots represent the outliers.

\subsection{Nutrients and Pathogens}

Spatio-temporal variations in organic nitrogen, $\mathrm{NO}_{3}-\mathrm{N}$, and $\mathrm{NH}_{3}-\mathrm{N}$ were significant (Figures 7-9). The highest concentrations of TKN were recorded at stations A9 $(50.4 \pm 19.3 \mathrm{mg} / \mathrm{L})$ and $\mathrm{RH}(34.4 \pm 12.3 \mathrm{mg} / \mathrm{L})$ during the summer months. At TG, significant variations $(p<0.05)$ in TKN were observed post-monsoon in comparison with summer and monsoon, with higher TKN observations in the post-monsoon season.

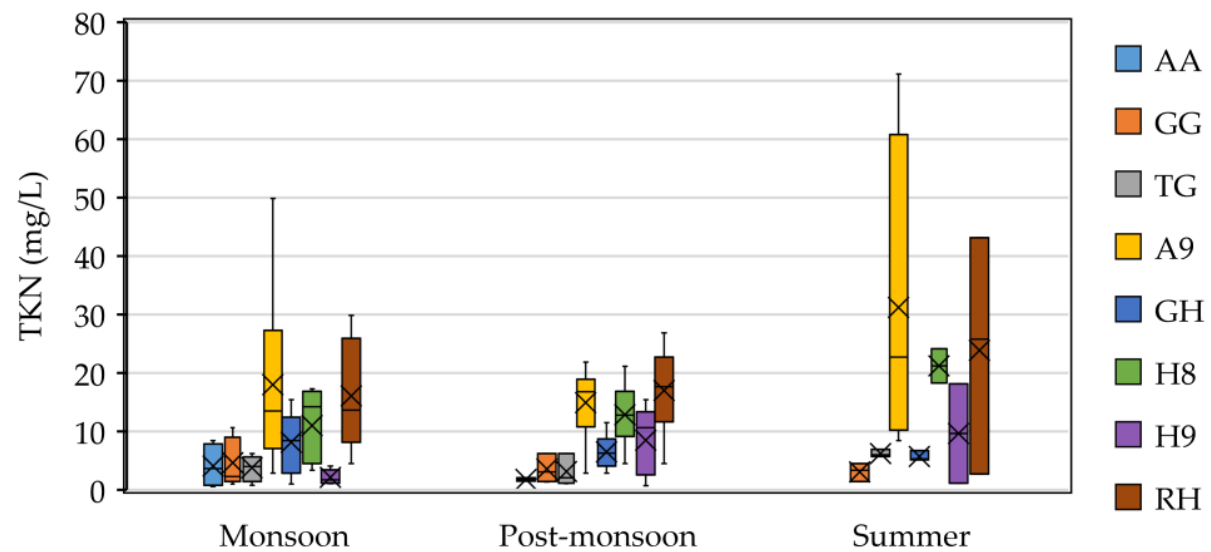

Figure 7. Seasonal variation of TKN in Powai Lake at different sampling locations shown as box plots. The top and bottom of the box indicate the 75th and 25th percentiles, line within the box represents median, cross represents mean, range bar represents the maximum and minimum values, and dots represent the outliers. 


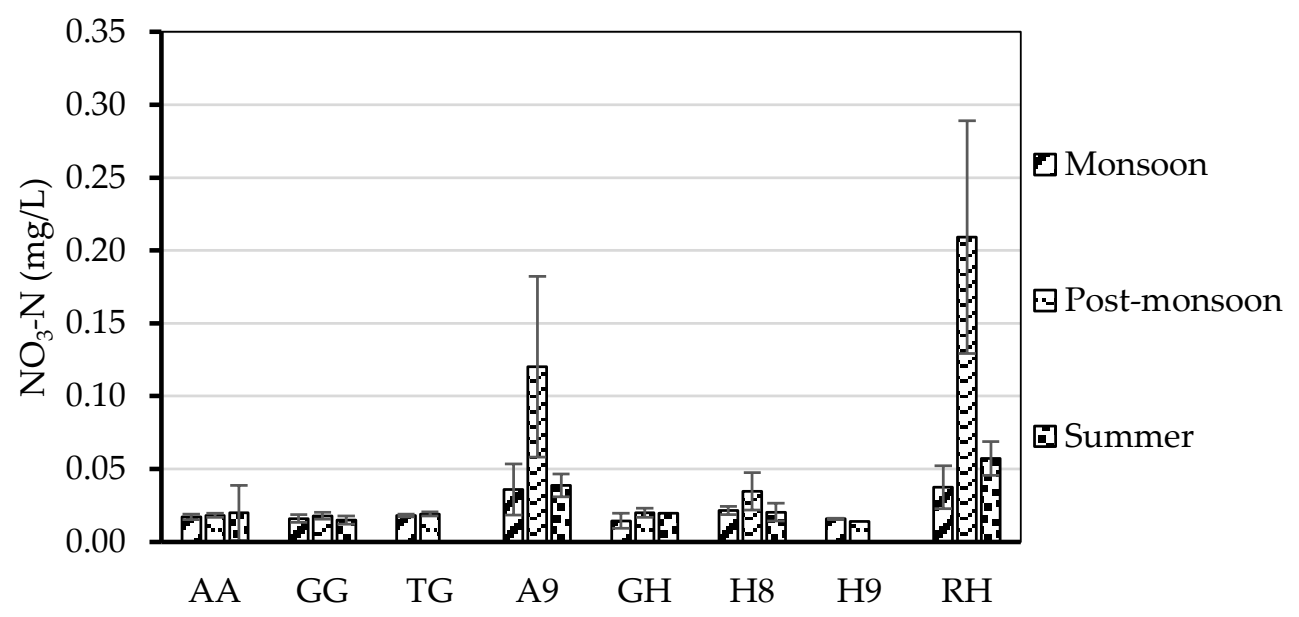

Figure 8. Seasonal variation of $\mathrm{NO}_{3}-\mathrm{N}$ in Powai Lake represented as mean at different sampling locations. Error bars represent standard deviation.

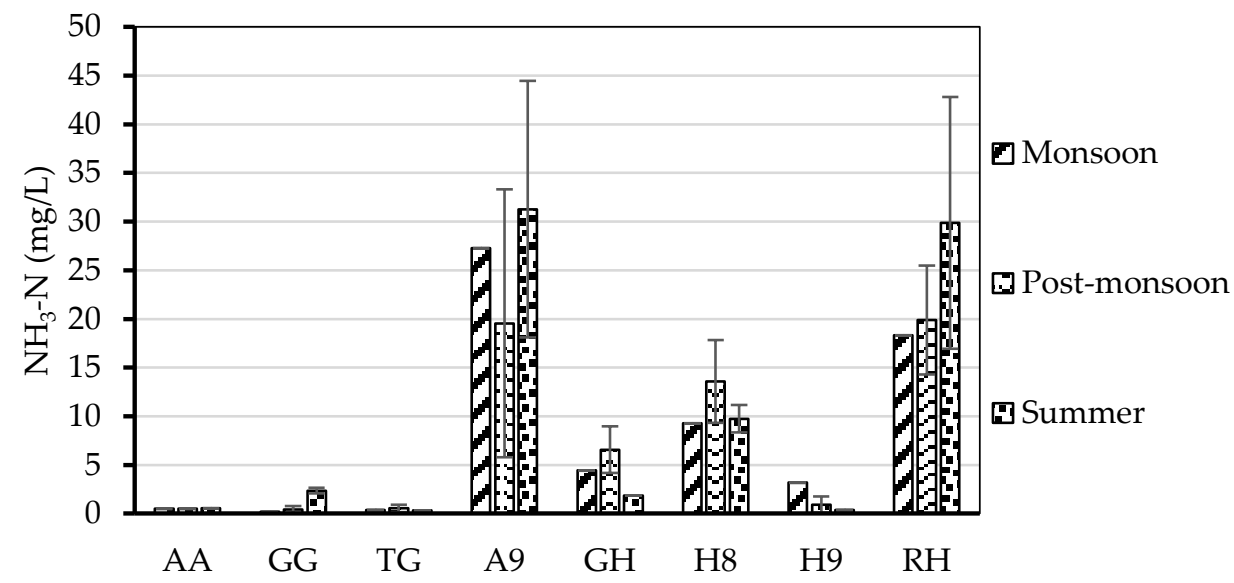

Figure 9. Seasonal variation of $\mathrm{NH}_{3}-\mathrm{N}$ in Powai Lake represented as mean at different sampling locations. Error bars represent standard deviation.

Similar to $\mathrm{COD}$ and $\mathrm{BOD}_{5}$ observed in the post-monsoon season at TG, organic nitrogen was also observed to be the highest in the post-monsoon season. Similarly, at station $\mathrm{H} 9$, TKN dynamics were comparable to $\mathrm{COD}$ and $\mathrm{BOD}_{5}$, with post-monsoon months witnessing higher concentrations and variations significantly $(p<0.05)$ differing from monsoon season. This is attributed to the natural sources bringing pollutants through runoff and erosion. TKN was not detected at AA station during summer months. Further, stations GG, A9, GH, H8, and RH did not exhibit any significant variations in TKN for the three seasons, implying similar nutrient loading. At the center of the Lake, lower concentrations $(1.87 \pm 0.77 \mathrm{mg} / \mathrm{L})$ were observed. The enrichments of nitrogen species in water bodies eventually induces anoxic conditions, toxicity in invertebrates, fish mortality, and algal blooms, resulting in habitat and biodiversity loss [64,65].

Unlike organic pollutants and other nutrients, merely a few incidences of elevated $\mathrm{NO}_{3}-\mathrm{N}$ were measured (Figure 8). $\mathrm{NO}_{3}-\mathrm{N}$ concentrations in the Lake varied between $<0.06$ $\mathrm{mg} / \mathrm{L}, 0.06-0.63 \mathrm{mg} / \mathrm{L}$, and $0.06-0.08 \mathrm{mg} / \mathrm{L}$, in monsoon, post-monsoon, and summer seasons respectively. Stations $\mathrm{A} 9$ and $\mathrm{RH}$ recorded the highest $\mathrm{NO}_{3}-\mathrm{N}$ in all seasons, though no seasonal variations were observed. The concentrations measured at $\mathrm{A} 9$ and $\mathrm{RH}$ imply the high $\mathrm{NO}_{3}-\mathrm{N}$ loadings due to wastewater inputs in monsoon season, and subsequent reduction owing to uptake by weeds and water hyacinths in summer.

The observed low $\mathrm{NO}_{3}-\mathrm{N}$ concentrations in the littoral zones of the present study compared to past studies in the limnetic zones [38-40] were attributed to nutrient retention by weeds and algal blooms in the Lake's littoral zone, converting $\mathrm{NO}_{3}-\mathrm{N}$ to $\mathrm{NH}_{3}-\mathrm{N}$ or 
elemental nitrogen. Further, the prevalence of $\mathrm{NO}_{3}-\mathrm{N}$ is reportedly highest in summer and post-monsoon seasons owing to fertilizer inputs, livestock rearing, and sewage inlets [59], and is recognized by concentrations in the range $0.5-1.5 \mathrm{mg} / \mathrm{L}$ in eutrophic lakes [65] as witnessed in the present study.

At least one incidence of elevated $\mathrm{NH}_{3}-\mathrm{N}$ was observed in all eight sampling stations, indicating the deposition of organic wastes at these sites (Figure 9). The highest concentrations of $\mathrm{NH}_{3}-\mathrm{N}$ were observed in $\mathrm{A} 9, \mathrm{H} 8$, and $\mathrm{RH}$. Levels of $\mathrm{NH}_{3}-\mathrm{N}>1.2 \mathrm{mg} / \mathrm{L}$ strongly compromise wildlife and fisheries in surface water bodies [66]. Such concentrations were observed at sampling stations $\mathrm{A} 9, \mathrm{GH}, \mathrm{H} 8$, and $\mathrm{RH}$ during all sampling months, with the highest recorded concentration of $48.7 \mathrm{mg} / \mathrm{L}$ at $\mathrm{RH}$ station during summer. Other stations with very high $\mathrm{NH}_{3}-\mathrm{N}(10-45 \mathrm{mg} / \mathrm{L})$ recorded include $\mathrm{A}$, $\mathrm{GH}$, and $\mathrm{H} 8$. Further, $\mathrm{NH}_{3}-\mathrm{N}>1.2 \mathrm{mg} / \mathrm{L}$ was also observed at GG during the summer season and at $\mathrm{H} 9$ during monsoon and post-monsoon seasons.

Moreover, ammonia nitrogen toxicity on fish is ten times more detrimental at $\mathrm{pH} 8$ as compared to $\mathrm{pH} 7$ [66]. As detailed earlier, in at least one of the sampling campaign months, lake water at sampling stations AA, GG, TG, GH, and H9 was observed with $\geq \mathrm{pH}$ 8. Alarmingly, these concentrations of $\mathrm{NH}_{3}-\mathrm{N}$ in the littoral zones were 30-40 times higher than the variations in the limnetic zone reported in past studies $[35,37]$. These high concentrations in the Lake's littoral zone may be attributed to the photosynthetic activities of weeds and algal blooms converting $\mathrm{NO}_{3}-\mathrm{N}$ to $\mathrm{NH}_{3}-\mathrm{N}$.

Seasonal variation of TP is shown in Figure 10. At the center of the Lake, average TP was $0.93 \pm 0.61 \mathrm{mg} / \mathrm{L}(n=16)$, with a maximum of $1.7 \mathrm{mg} / \mathrm{L}$ in the monsoon and post-monsoon seasons. TP concentrations in the Powai Lake periphery ranged between $\mathrm{BDL}-2.78 \mathrm{mg} / \mathrm{L}, \mathrm{BDL}-1.49 \mathrm{mg} / \mathrm{L}$, and $0.05-2.45 \mathrm{mg} / \mathrm{L}$ in monsoon, post-monsoon, and summer seasons, respectively. These values were 10 times higher than the reported concentrations in the limnetic zones over the past decade [37,38] and TP concentrations reported in 2016-2017 [40] were similar to the present study. TP is a limiting factor for algal growth $[65,67]$ and should remain below $50 \mu \mathrm{g} / \mathrm{L}$ to reduce the risk of algal blooms [59]. At least one incidence of high TP $(>0.05 \mathrm{mg} / \mathrm{L})$ was observed in all the stations, with the highest concentrations detected during summer and post-monsoon months.

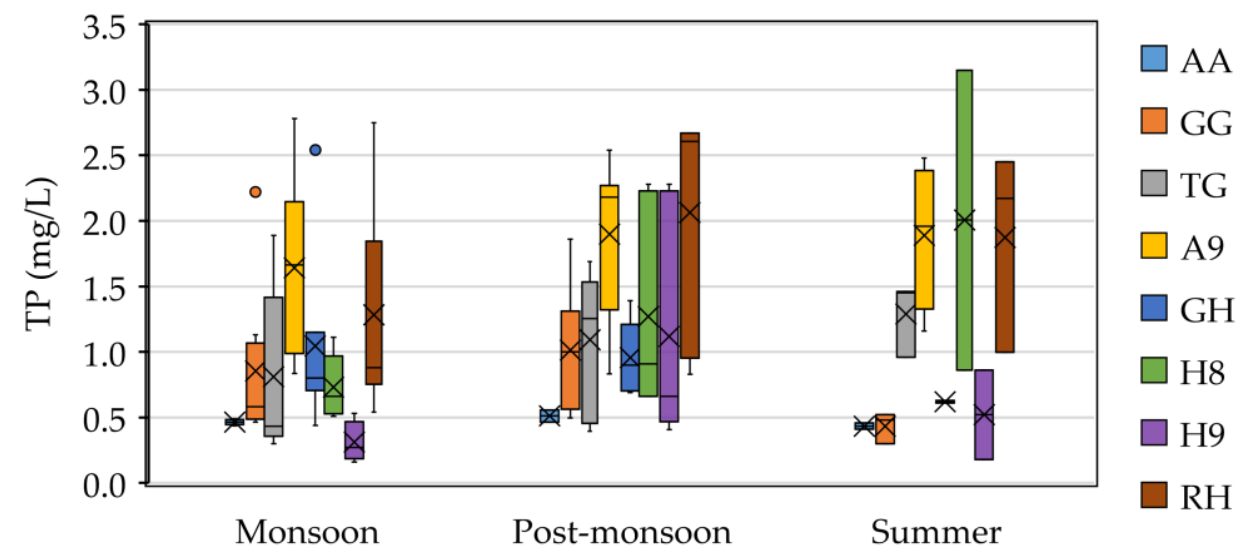

Figure 10. Seasonal variation of TP in Powai Lake at different sampling locations shown as box plots. The top and bottom of the box indicate the 75th and 25th percentiles, line within the box represents median, cross represents mean, range bar represents the maximum and minimum values, and dots represent the outliers.

No significant temporal variations were observed in any of the sampling stations and H9 had the lowest concentration in all seasons $(p<0.05)$. The few incidences of elevated TP concentrations (up to $0.53 \mathrm{mg} / \mathrm{L}$ ) at $\mathrm{H} 9$ were attributed to internal phosphorous loading. Phosphorous accumulated in lake sediments, particularly those bound to iron compounds, which are redox sensitive, are mobile in nature and eventually released into water [68]. The nutrient sources of the lake can be examined through the N:P ratios in the pelagic zone of 
the water resource. N:P ratios in lakes ranging from 20 to $>200$ have been associated with precipitation, groundwater, and nutrient export from lands and soils. N:P between 10 and $<1$ is often associated with sediments, sewage, and urban runoff [67]. From the present study, N:P ratios in the littoral and limnetic zones range between 2 and 11, evidencing nutrient loads from sediments, sewage, and urban runoff. Likewise, the evidence of organics and nutrients at the Lake's center highlights the chronic nature of pollution in Powai Lake.

In the present study, all the eight sampling stations in the Lake periphery showed fecal coliform contamination; no significant variations were identified due to insufficient data points (Figure 11). Maximum fecal coliform densities reached up to $2 \times 10^{4} \mathrm{CFU} / 100$ $\mathrm{mL}$ during summer months at station $\mathrm{RH}$, followed by $\mathrm{H} 8$ with $1.6 \times 10^{4} \mathrm{CFU} / 100 \mathrm{~mL}$, inferring that the highest sewage contamination occurred at these sites. Fecal coliforms were not detected for the samples collected from the center; however, the contamination of pathogens at the center of the Lake cannot be ruled out. The sampling events at the center of the lake were insufficient to establish a statistically significant result.

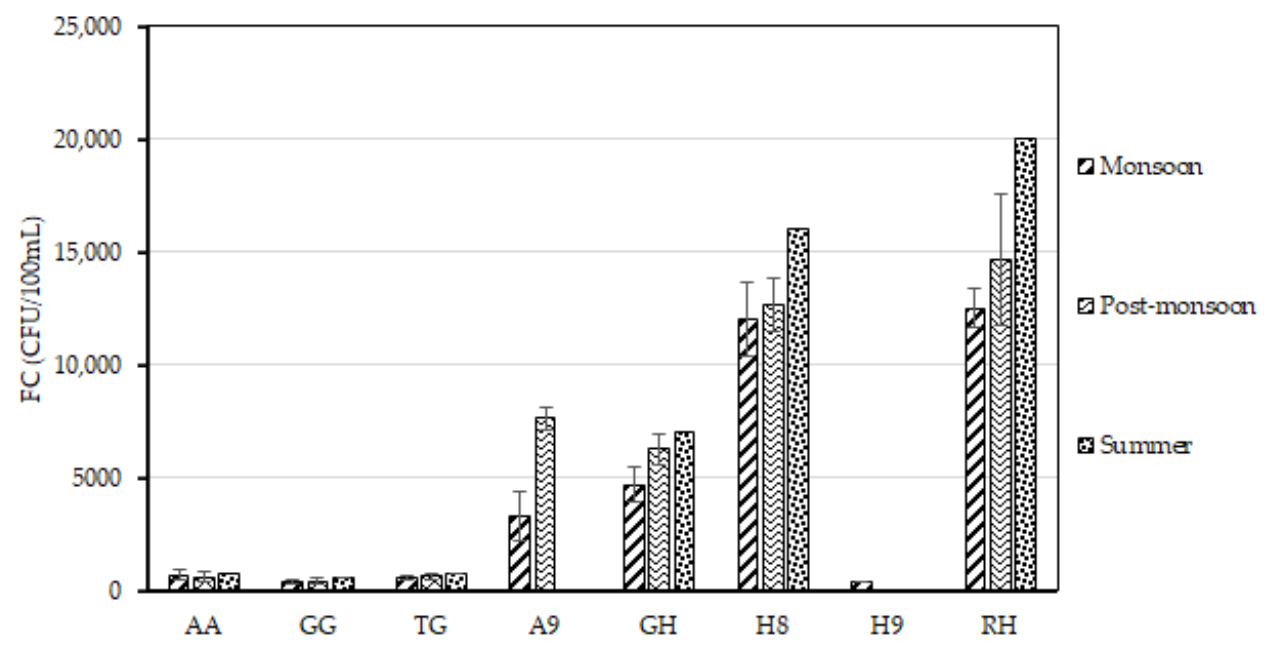

Figure 11. Seasonal variation of fecal coliform in Powai Lake represented as mean at different sampling locations. Error bars represent standard deviation.

As per USEPA [69], $<410 \mathrm{CFU} / 100 \mathrm{~mL}$ is the recommended maximum statistical threshold value for total coliforms in recreational water bodies. All eight locations in the Lake periphery had FC concentrations that made them unfit for recreational purposes. Threshold values for pathogens (total coliform $/ 100 \mathrm{~mL}$ ) in water bodies used as Class A (drinking water source), Class B (outdoor bathing), or Class C (drinking water source after conventional treatment) by СРСВ [47] are $<50,<500$, and $<5000$ respectively. Thus, Powai Lake water does not qualify as a source for Class A, Class B, or Class C use.

The presence of potentially pathogenic bacteria (indicated by FC of $4 \times 10^{2} \mathrm{CFU} / 100$ $\mathrm{mL}$ ) at station H9 was unexpectedly observed in the 2018 monsoon. Reportedly, fecal coliforms and Escherichia coli can possibly survive even in nonhost habitats in aquatic ecosystems such as algae, zooplankton, turtles, and fish. In addition to sewage disposal, other predominant sources of fecal indicator bacteria identified were birds, dogs, seabirds, and waterfowl [70]. The habitat in the vicinity of station H9 in Powai Lake has, in fact, been frequented by many of such species that might have contributed to fecal contamination. Few other lakes in India have been studied with respect to the influence of urban settlements. Fecal coliforms reported in Nainital Lake in Dehradun with $14 \times 10^{4}$ MPN/100 $\mathrm{mL}$ [71], and Kankaria Lake and Chandola Lake in Ahmedabad with $15 \times 10^{5} \mathrm{CFU} / 100$ $\mathrm{mL}$ and $34 \times 10^{4} \mathrm{CFU} / 100 \mathrm{~mL}$, respectively [72], are comparable to the present study. 


\subsection{Water Quality Index for Powai Lake}

Powai Lake's WQI (Figure 12) indicated that no station monitored in Powai Lake could be considered of 'excellent quality' or 'good quality'. The 'bad quality' of water at stations GG, TG, and GH could be attributed to the religious events and other activities such as recreation, fishing, bathing, and cattle rearing. Further, water quality monitoring reveals that stations A9, H8, and RH observed very high organic, nutrient, and pathogen loadings indicating that urban runoff primarily discharges from informal settlements at these sites. AA and H9 were observed with a 'medium quality' (51-70) index, owing to relatively lower pollution loads. The improved water quality at $\mathrm{H} 9$ is an implication of overflow water received from Vihar Lake. Similarly, occasional fishing was the only major anthropogenic activity observed at station AA, though urban surface runoff bringing pollutants at the site is likely. There was discrete seasonal variation in water quality at AA station as described in Sections 3.3 and 3.4; however, the index value (51) for AA reflects enhanced water quality. This may be attributed to the annual average concentrations considered for all pollutants while calculating WQI at AA station.

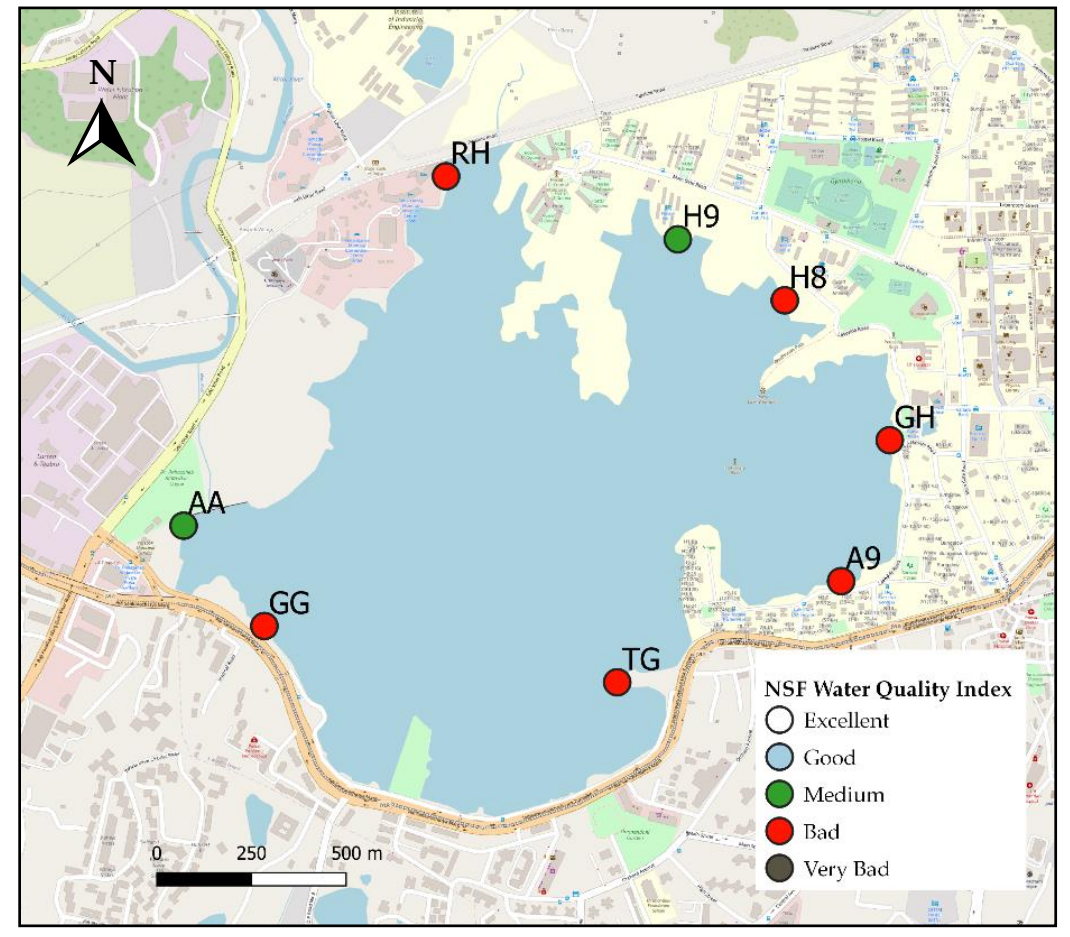

Figure 12. Water quality indexes mapped at different sampling locations along the periphery of Powai Lake.

\section{Rejuvenation Plan for Powai Lake}

The key issues identified in the present study for degradation of Powai Lake include anthropogenic activities occurring in and around the Lake, including idol immersion, discharge of solid wastes, sewage discharge from domestic and commercial sources, presence of water hyacinth and weeds, slit deposition, etc. The fundamental objective of a rejuvenation strategy should not only be to attain regulatory compliance but also to maintain a high quality of water suitable for recreation, performing religious rituals, process water for industry, and irrigation [1]. A summary rejuvenation plan (Figure 13) for Powai Lake was prepared using the inputs received from water quality monitoring data and through the capacity building of other accountable stakeholders, especially the citizen scientists. The plan was structured in three phases. 
Rejuvenation Plan for Powai Lake

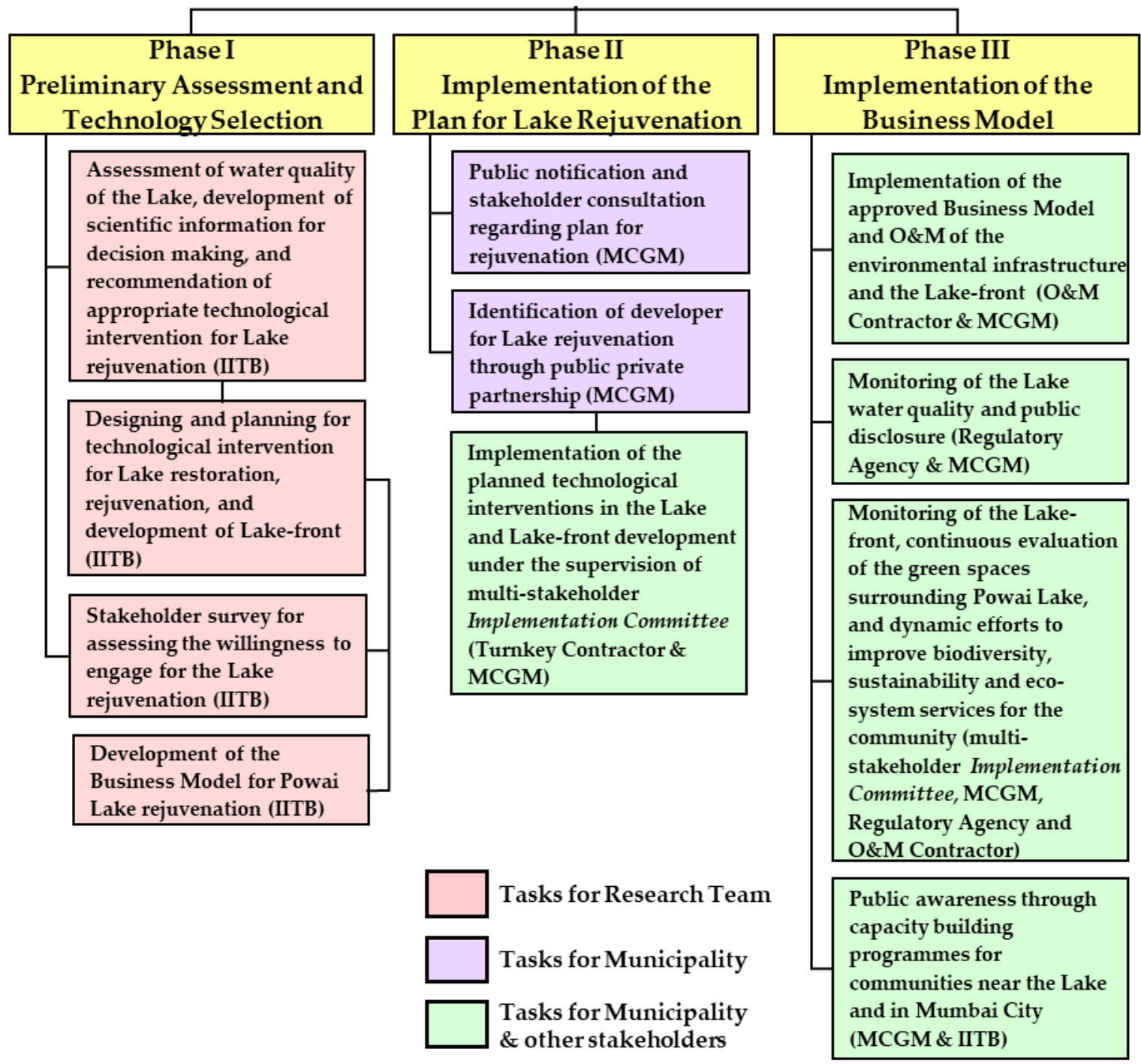

Figure 13. The proposed phase-wise plan for rejuvenation of Powai Lake and the associated tasks.

\subsection{Phase I: Preliminary Assessment and Technology Selection}

Phase I focuses on creating the groundwork and information flows to facilitate a sustainable rejuvenation and provide support for an appropriate technological intervention. This phase was initiated in the present project, with the support of the citizen scientists. This phase also includes an evaluation of potential technological actions to achieve lake rejuvenation and a stakeholder survey, which will help in the development of a Business Model.

NTSs are eco-technologies that enable the reestablishment of natural processes for pollution control with improved efficacy. A variety of NTSs recognized for wastewater treatment comprise CWs, natural wetlands, algal ponds, duckweed ponds, sewage-fed fish ponds, hyacinth ponds, etc. [6]. Among these NTSs, CW is one of the promising technologies that utilize plants and associated rhizospheric microorganisms for removal of pollutants from wastewater, and their applications in India have been investigated by many researchers $[1,2,6,7,73]$. CWs are gaining attention due to their extensive applicability all over the world, India in particular, owing to their simple construction and easy operation and maintenance in tropical climates, as well as cost effectiveness $[2,6,7,11-13,74-77]$. In India, CWs have been considered to be the most appropriate technology for wastewater treatment among the 108 NTSs studied in operation [7]. 
The decentralized eco-centric technology titled 'CW4Reuse', which is a variant of horizontal subsurface flow constructed wetland (HSSF-CW) has been developed to treat domestic wastewaters [11-13,76]. This $\mathrm{NbS}$ is capable of achieving climate change mitigation, pollution control in air, land, and water, conservation of biodiversity, restoration of ecosystem services, and re-naturing the urban environment, thereby creating resilient landscapes and cities leading to socio-economic transformation of rural and peri-urban areas. Other benefits of this approach have been associated to empowerment of women and creation of green jobs [78-80]. Owing to the sub-surface flow of water in the constructed wetland bed, this technology also eliminates the possibility of breeding of disease vectors, including mosquitoes.

By assessing the pollution sources in the present study, three zones of pollution were divided as Area-I (i.e., A9, GH, H8, and RH), Area-II (i.e., AA, GG, and TG), and Area-III (i.e., H9). Area-I was identified as stations receiving the highest pollution through the discharge of partially treated wastewaters, Area-II represents stations influenced by anthropogenic activities (e.g., fishing, religious rituals, cattle rearing), and Area-III was recognized for receiving natural sources of pollution. Specific actions for pollution control for Area-I include the interception, diversion, and treatment of inlets using 'CW4Reuse'. Restrictions on anthropogenic activities in Area-II are identified in conjunction with appropriate riparianzone treatment. Area-III can be revitalized in situ using floating constructed wetlands.

In Powai Lake and its surrounding urban area, the blue-green balance needs to be improved; therefore, CW4Reuse technology was identified as the most suitable not only for the improvement of lake water quality but also for the expansion of green patches on the landward side of the lake-front. Further, surface runoff can also be reduced due to its natural filtering effects. The final task of Phase 1 was the stakeholder survey for the assessment of the willingness to participate in Powai Lake rejuvenation (manuscript in progress). Lastly, the development of a comprehensive Business Model for the technological intervention selected for rejuvenation has to be undertaken in Phase I.

\subsection{Phase II: Implementation of Plan for Rejuvenation}

The second phase of the rejuvenation plan comprises the implementation of the selected technology. The initial task involved in Phase II to be undertaken by the municipality (MCGM) is the public notification and stakeholder consultation regarding the plan for rejuvenation, followed by identification of a developer and implementation of a rejuvenation plan for the Lake and lake-front.

At the outset of Phase II, a multi-stakeholder 'Implementation Committee' will be set up to supervise the action plan, selecting members from the Departments of Environment, Water Resources, Public Works, Public Health, Tourism, Regulatory Agencies, and Revenue, as well as representatives from NGOs and community-based organizations (CBOs). Such a committee would be convened by the Lake Protection Authority and advised by IITB as the knowledge partner to monitor the stages of the restoration of Powai Lake. The progress of the tasks in this phase would be reported to the 'Implementation Committee' and their feedback would have to be addressed.

The first task in Phase II is to communicate the rejuvenation plan of Powai Lake to the surrounding community and other citizens of Mumbai. Such disclosures are typically disseminated through the formal municipal orders as well as via newspapers, public forums, magazines, and television news. This will help in educating the public and thereby create a sense of responsibility towards the Lake and their ownership in the rejuvenation process.

Subsequently, the second task is the identification of the developer and financing sources, optimally through a public-private partnership. CPHEEO [54] recommended a tripartite arrangement between a funding agency (private or a public source), implementing agency (public trust or private entity), and the State Government, as the most transparent and efficient. A comprehensive SWOT analysis is also suggested [81]. 
The third task is the planned technological intervention and lake-front development. One of the initial steps in lake-front development is the precise mapping and demarcation of the Lake's boundary with the direction of the Revenue Department to identify potential lake encroachers and manage their relocation and resettlement. Reconstruction of inlets and outlets, dredging, de-silting and de-weeding, construction of silt traps in the inlet points, setting up of low-cost sanitation provisions in and around the Lake, construction of lake fence and shore-line, building embankments, and construction of greenways for walking and leisure, fountains, and lighting are the lake-front development considerations. Separate artificial ponds can be constructed for citizens to conduct their religious activities near the Lake. Unauthorized activities and management of solid waste littering is also essential to the execution of the rejuvenation plan.

\subsection{Phase III: Implementation of the Business Model}

Current breakthroughs in sustainable development models have shifted the paradigm from traditional approaches of lake restoration as a 'potential cost to economic production' to an 'ecosystem service function' to be derived from revitalized urban green-blue spaces [82-84]. A multidimensional approach of a 'Circular Business Model' is recommended [85] and other studies demonstrate that place-led and nature-led solutions are the hallmarks of circular territorial projects. With the same spirit, the Business Model developed for Powai Lake should deliver a multifunctional strategy that addresses Powai Lake restoration and revitalizes the urban landscape through ecotourism. The implementation of the Business Model for rejuvenation of Powai Lake that provides for the operations of the environmental infrastructure is the primary focus in Phase III (Figure 13). Biodiversity, sustainability, and ecosystem services for the community should be the overall objectives of the Business Model where the user will pay for utilities derived from the ecosystem.

The environmental and regulatory responses of the ecosystem restoration of Lake Rotorua used the drivers-pressures-state-impact-response framework and a lack of awareness of environmental issues and social lag times in responding to ecosystem decline were the factors that led to regulatory response failures of lake restoration. To overcome these shortcomings, ecological factors, economic interests, and societal limitations should follow an interdisciplinary approach [86].

Phase III will also include capacity building for the local communities, monitoring of lake water quality, and periodic public disclosures by the regulatory agency and municipality. These are long-term tasks that need to be functionalized by the multi-stakeholder 'Implementation Committee'. For a successful implementation of the restoration tasks, Powai Lake and the periphery should be declared an 'eco-sensitive area' through a formal notification to rule out detrimental real-estate development on the lake-front. The capacity building workshops for the local community and other residents in Mumbai would involve major stakeholders such as members from the 'Implementation Committee', municipal authority, and all partners of the funding agency.

The Powai Lake rejuvenation plan not only focuses on reviving the quality of water but also directs the restoration through the transformation of its entire locale by adopting ecocentric technologies in partnership with the community, and is in line with UN Sustainable Development Goals 6, 11, and 17 [5].

\section{Conclusions}

Powai Lake is threatened by the ingress of untreated domestic wastewaters from informal settlements and surface runoff. The present study shows that these conditions continue to degrade the lake ecosystem. The capacity building of citizen scientists and other stakeholders is the first key step in a phased rejuvenation plan. Importantly, there is no time to waste; public awareness has risen, also thanks to the present project, and the condition of the Lake should not deteriorate any further.

The water quality of the Lake was assessed in a large number of sites for 21 months. These results underline the chronic pollution nature in the Lake. Organic pollutant loading, 
nutrient enrichment, and pathogenicity characterized much of the littoral zone with significant spatial and temporal variations. Their impacts are extended to the limnetic zone evidenced by infestation of weeds including water hyacinth.

Based on this evidence, a three-phase rejuvenation plan aims at restoration through employing environmentally and socially sustainable technology. If one aims at restoration of Powai Lake and its ecological niche, one will have to reverse the decades of pollution and the ecological degradation of the aquatic ecosystem and the surrounding green spaces. Clearly, unless the waste management system in the surrounding community is upgraded, the rejuvenation efforts of the Lake will not succeed.

In summary, the rejuvenation of Powai Lake can only be achieved through adopting an integrated approach, in which the disconnect between the need for conservation of environment and ecology of the Lake and the development in the green space around the Lake should be addressed with priority. Ensuring the participation of the stakeholder community residing around the Lake is equally important in implementing the rejuvenation plan. The management plan is a holistic approach that understands and recognizes the Lake as a system, not only focusing on the improvement of water quality; but also on the associated ecosystem services delivered to the local and larger community.

Author Contributions: Conceptualization, S.R.A.; methodology, B.L. and R.S.S.; investigation and formal analysis, B.L. and D.S.; data curation, B.L., D.S., R.S.S., R.S. (Richa Singh), S.D.P., A.M.K., S.S.; writing—original draft preparation, B.L.; writing—review and editing, S.R.A., S.L., R.S. (Raghuvansh Saxena); supervision, project administration, funding acquisition, S.R.A. All authors have read and agreed to the published version of the manuscript.

Funding: This research was funded by the Earthwatch Institute India Trust, grant number 100013240.

Institutional Review Board Statement: Not applicable.

Informed Consent Statement: Not applicable.

Data Availability Statement: Not applicable.

Acknowledgments: The authors would like to acknowledge the funding received from the Earthwatch Institute India Trust, grant number 100013240. In addition, the authors gratefully acknowledge the partial funding received from the Indian Institute of Technology Bombay and the 'Capacity Building in Sustainability and Environmental Management' (CapSEM) Project funded by the EU program Erasmus+. The contribution and enthusiasm of citizen scientists (in collaboration with the IIT Bombay Team) in water quality monitoring are also acknowledged.

Conflicts of Interest: The authors declare no conflict of interest. The funders had no role in the design of the study; in the collection, analyses, or interpretation of data; in the writing of the manuscript, or in the decision to publish the results.

\section{References}

1. Asolekar, S.R.; Kalbar, P.P.; Chaturvedi, M.K.M.; Maillacheruvu, K. Rejuvenation of Rivers and Lakes in India: Balancing Societal Priorities with Technological Possibilities. In Comprehensive Water Quality and Purification; Ahuja, S., Ed.; Elsevier: Waltham, MA, USA, 2014; pp. 181-229.

2. Kumar, D.; Sharma, S.K.; Asolekar, S.R. Significance of incorporating constructed wetlands to enhance reuse of treated wastewater in India. In Natural Water Treatment Systems for Safe and Sustainable Water Supply in the Indian Context: Saph Pani; Wintgens, T., Nattorp, A., Elango, L., Asolekar, S.R., Eds.; IWA Publishing, Gb: London, UK, 2016; pp. 161-176.

3. Sutar, R.S.; Lekshmi, B.; Kamble, K.A.; Kharat, M.; Ranade, D.R.; Parikh, Y.J.; Asolekar, S.R. How Do We Transition to the Integrated Management of Water Cycle? J. Indian Water Work. Assoc. 2018, 1, 9-13.

4. Ministry of Housing and Urban Affairs. Schemes/Programmes. Ministry of Housing and Urban Affairs, Government of India. Available online: http:/ / mohua.gov.in/cms/schemes-or-programmes.php (accessed on 18 May 2021).

5. United Nations. Transforming Our World: The 2030 Agenda for Sustainable Development. 2015. Available online: https: //www.un.org/ga/search/view_doc.asp?symbol=A/RES/70/1\&Lang=E (accessed on 5 February 2021).

6. Arceivala, S.J.; Asolekar, S.R. Wastewater Treatment for Pollution Control and Reuse, 3rd ed.; McGraw Hill Education India Pvt. Ltd.: New Delhi, India, 2006.

7. Kumar, D.; Asolekar, S.; Sharma, S. Post-Treatment and Reuse of Secondary Effluents Using Natural Ltreatment Systems: The Indian Practices. Environ. Monit. Assess. 2015, 187, 1-15. [CrossRef] 
8. Hutchins, M.; Fletcher, D.; Hagen-Zanker, A.; Jia, H.; Jones, L.; Li, H.; Loiselle, S.; Miller, J.; Reis, S.; Seifert-Dähnn, I.; et al. Why Scale Is Vital to Plan Optimal Nature-Based Solutions for Resilient Cities. Environ. Res. Lett. 2021, 16, 044008. [CrossRef]

9. Nagendra, H. Restoration of the Kaikondrahalli Lake in Bangalore: Forging a New Urban Commons; Kalpavriksh: Pune, India, 2016; Available online: http:/ / data.opencity.in/Documents/Recent/Kaikondrahalli-lake-case-study-June-2016.pdf (accessed on 13 March 2021).

10. Sen, A.; Nagendra, H. Local Community Engagement, Environmental Placemaking and Stewardship by Migrants: A Case Study of Lake Conservation in Bengaluru, India. Landsc. Urban Plan. 2020, 204, 103933. [CrossRef]

11. Lekshmi, B.; Sharma, S.; Sutar, R.S.; Parikh, Y.J.; Ranade, D.R.; Asolekar, S.R. Circular Economy Approach to Women Empowerment Through Reusing Treated Rural Wastewater Using Constructed Wetlands. In Waste Management as Economic Industry towards Circular Economy; Ghosh, S.K., Ed.; Springer: Singapore, 2020; pp. 1-10.

12. Lekshmi, B.; Sutar, R.S.; Ranade, D.R.; Parikh, Y.J.; Asolekar, S.R. Enhancement of Water Reuse by Treating Wastewater in Constructed Wetlands: Minimization of Nutrients and Fecal Coliform. In Sustainable Environmental Geotechnics; Reddy, K.R., Agnihotri, A.K., Aksoy, Y.Y., Dubey, B.K., Bansal, A., Eds.; Springer: Cham, Switzerland, 2020; Volume 89, pp. $213-223$.

13. Sutar, R.S.; Lekshmi, B.; Ranade, D.R.; Parikh, Y.J.; Asolekar, S.R. Towards enhancement of water sovereignty by implementing the 'constructed wetland for reuse' technology in gated community. In Sustainable Environment and Infrastructure; Reddy, K.R., Agnihotri, A.K., Yukselen-Aksoy, Y., Dubey, B.K., Bansal, A., Eds.; Springer: Cham, Switzerland, 2021; Volume 90, pp. 157-163.

14. NITI Aayog; UNDP. Lake Restoration: Two successful models of lake restoration in Rajasthan (Mansagar) and Karnataka (Kaikondrahalli). In Social Sector Service Delivery: Good Practices Resource Book; NITI Aayog: New Delhi, India, 2015 ; pp. 83-88.

15. Vasistha, P.; Ganguly, R. Water Quality Assessment of Natural Lakes and Its Importance: An Overview. Mater. Today 2020, 32, 544-552. [CrossRef]

16. Gura, T. Citizen Science: Amateur Experts. Nature 2013, 496, 259-261. [CrossRef] [PubMed]

17. Rise of the Citizen Scientist. Nature 2015, 524, 265. [CrossRef]

18. McKinley, D.C.; Miller-Rushing, A.J.; Ballard, H.L.; Bonney, R.; Brown, H.; Cook-Patton, S.C.; Evans, D.M.; French, R.A.; Parrish, J.K.; Phillips, T.B.; et al. Citizen Science Can Improve Conservation Science, Natural Resource Management, and Environmental Protection. Biol. Conserv. 2017, 208, 15-28. [CrossRef]

19. Thornhill, I.; Loiselle, S.; Lind, K.; Ophof, D. The Citizen Science Opportunity for Researchers and Agencies. Bioscience 2016, 66, 720-721. [CrossRef]

20. Walker, D.W.; Smigaj, M.; Tani, M. The Benefits and Negative Impacts of Citizen Science Applications to Water as Experienced by Participants and Communities. WIREs Water 2020, 8, e1488. [CrossRef]

21. Cárdenas, M.; Wilde, V.; Hagen-Zanker, A.; Seifert-Dähnn, I.; Hutchins, M.; Loiselle, S. The Circular Benefits of Participation in Nature-Based Solutions. Sustainability 2021, 13, 4344. [CrossRef]

22. Szabo, J.K.; Vesk, P.A.; Baxter, P.W.J.; Possingham, H.P. Regional Avian Species Declines Estimated from Volunteer-Collected Long-Term Data Using List Length Analysis. Ecol. Appl. 2010, 20, 2157-2169. [CrossRef]

23. Belt, J.J.; Krausman, P.R. Evaluating Population Estimates of Mountain Goats Based on Citizen Science. Wildl. Soc. Bull. 2012, 36, 264-276. [CrossRef]

24. Mason, L.; Arathi, H.S. Assessing the Efficacy of Citizen Scientists Monitoring Native Bees in Urban Areas. Glob. Ecol. Conserv. 2019, 17, e00561. [CrossRef]

25. Uhrin, A.V.; Lippiatt, S.; Herring, C.E.; Dettloff, K.; Bimrose, K.; Butler-Minor, C. Temporal Trends and Potential Drivers of Stranded Marine Debris on Beaches within Two US National Marine Sanctuaries Using Citizen Science Data. Front. Environ. Sci. 2020, 8, 232. [CrossRef]

26. Pudifoot, B.; Cárdenas, M.L.; Buytaert, W.; Paul, J.D.; Narraway, C.L.; Loiselle, S. When It Rains, It Pours: Integrating Citizen Science Methods to Understand Resilience of Urban Green Spaces. Front. Water 2021, 3, 33. [CrossRef]

27. Abu Ali, M.; Alawadi, K.; Khanal, A. The Role of Green Infrastructure in Enhancing Microclimate Conditions: A Case Study of a Low-Rise Neighborhood in Abu Dhabi. Sustainability 2021, 13, 4260. [CrossRef]

28. Hadj-Hammou, J.; Loiselle, S.; Ophof, D.; Thornhill, I. Getting the Full Picture: Assessing the Complementarity of Citizen Science and Agency Monitoring Data. PLoS ONE 2017, 12, e0188507. [CrossRef]

29. Cunha, D.G.F.; Magri, R.A.F.; Tromboni, F.; Ranieri, V.E.L.; Fendrich, A.N.; Campanhão, L.M.B.; Riveros, E.V.; Velázquez, J.A. Landscape Patterns Influence Nutrient Concentrations in Aquatic Systems: Citizen Science Data from Brazil and Mexico. Freshw. Sci. 2019, 38, 365-378. [CrossRef]

30. Rao, S.; Mogili, N. New Classification Method to Evaluate Pollution Levels of Sewage Contaminated Lakes. Sustainability 2021, 13, 3677. [CrossRef]

31. Zhang, Y.; Loiselle, S.; Zhang, Y.; Wang, Q.; Sun, X.; Hu, M.; Chu, Q.; Jing, Y. Comparing Wetland Ecosystems Service Provision under Different Management Approaches: Two Cases Study of Tianfu Wetland and Nansha Wetland in China. Sustainability 2021, 13, 8710. [CrossRef]

32. Chavan, A.; Mukherji, S. Response of an Algal Consortium to Diesel under Varying Culture Conditions. Appl. Biochem. Biotechnol. 2009, 160, 719-729. [CrossRef] [PubMed]

33. Chatterjee, A.; Sicheritz-Pontén, T.; Yadav, R.; Kondabagil, K. Genomic and metagenomic signatures of giant viruses are ubiquitous in water samples from sewage, inland lake, waste water treatment plant, and municipal water supply in Mumbai, India. Sci. Rep. 2019, 9, 1-9. [CrossRef] [PubMed] 
34. Radhakrishnan, C.; Kulikovskiy, M.; Glushchenko, A.; Kuznetsova, I.; Karthick, B. A First Finding and Morphology of the Neglected Diatom Genus Pseudostaurosiropsis from Anthropogenically Impacted Urban Lake in India. Inland Water Biol. 2020, 13, 170-177. [CrossRef]

35. Chatterjee, B. Pollution Level at Mumbai's Powai Lake 8 Times above Safe Limit, Says Environment Ministry. Hindustan Times. 18 December 2017. Available online: https:/ / www.hindustantimes.com/mumbai-news/pollution-level-at-powai-lake-8-timesabove-safe-standards-environment-ministry/story-taR1xJhKWm0QisIDpYiOOK.html (accessed on 17 May 2021).

36. Koliyar, J.G.; Rokade, N.S. Water quality in Powai lake: Mumbai, Maharashtra. In Proceedings of the Taal2007: The 12th World Lake Conference, Jaipur, Rajasthan, India, 28 October-2 November 2007; Sengupta, M., Dalwani, R., Eds.; 2008; pp. $1655-1659$.

37. Salaskar, P.; Gordon, R.; Yeragi, S. Environmental Status of Powai Lake, Mumbai (India). In Proceedings of the Taal2007: The 12th World Lake Conference, Jaipur, Rajasthan, India, 28 October-2 November 2007; Sengupta, M., Dalwani, R., Eds.; 2008; pp. 1650-1654.

38. Ratheesh Kumar, R.; Purushothaman, C.S.; Sreekanth, G.B.; Manju Lekshmi, N.; Renjith, V.; Sandeep, K.P.; Pandey, P.K. State of Water Quality of Two Tropical Urban Lakes Located at Mumbai Megacity. Int. J. Sci. Res. 2015, 4, 2319-7064.

39. Salaskar, P.; Muley, E.V. Strategy for conservation and Management of Urban lakes in Mumbai. In Lake Ecosystem Health and Its Resilience: Diversity and Risks of Extinction: Proceedings of the 16th World Lake Conference, Bali, Indonesia, 7-11 November 2016; Maghfiroh, M., Dianto, A., Jasalesmana, T., Melati, I., Samir, O., Kurniawan, R., Eds.; Research Center for Limnology, Indonesian Institute of Sciences: Jakarta, Indonesia, 2016; pp. 70-76.

40. Usman, A.; Dube, K.; Shukla, S.P.; Salaskar, P.; Prakash, C.; Sawant, P.B.; Singh, R. Water Quality Index as a Tool for Assessment of Status of an Urban Lake of Mumbai. Int. J. Curr. Microbiol. Appl. Sci. 2018, 7, 520-533. [CrossRef]

41. Rasal, V.; Patil, U.; Bhot, M. Assessment of Water Quality of Ten Urban Lakes in Mumbai. J. Aquat. Biol. Fish. 2019, 7, 110-114.

42. Surya, S.; Langde, A.; Deshmukhe, G.; Gop, A.; Ramteke, K.K.; Kumar, J. Fish Community Structure and Trophic Status-A Measure of Ecological Degradation: A Case Study from Powai Lake Mumbai. Int. J. Ecol. Environ. Sci. 2018, 44, 373-382.

43. Mahale, A.; Deshpande, T. A Metro Line in Search of a Car Shed. The Hindu. 21 December 2019. Available online: https: / / www.thehindu.com/news/national/a-metro-line-in-search-of-a-car-shed/article30362156.ece (accessed on 12 June 2021).

44. Bhagat, S. City's Flora \& Fauna Live on in Little Isles. The Times of India. 1 June 2011. Available online: https: / timesofindia indiatimes.com/city/mumbai/citys-flora-fauna-live-on-in-little-isles/articleshow/8673663.cms (accessed on 12 June 2021).

45. Rodricks, G. Powai: Anglers' Paradise Lost. The Maharashtra State Angling Association. 24 October 1998. Available online: https:/ / msaapowai.tripod.com/paradiselost.htm (accessed on 12 June 2021).

46. Thakkar, M. Powai Lake Has Crocodiles, Can't Allow Water Sports: Civic Body. Hindustan Times. 9 July 2019. Available online: https: / / www.hindustantimes.com/mumbai-news/powai-lake-has-crocodiles-can-t-allow-water-sports-civic-body / story-mKreilx1UiU61Qu3jIDbyL.html (accessed on 12 June 2021).

47. CPCB. Guidelines for Water Quality Monitoring; MINARS/27/2007-08; Ministry of Environment, Forest and Climate Change, Govt. of India: New Delhi, India, 2007.

48. American Public Health Association. Standard Methods for the Examination of Water and Wastewater, 23th ed.; Rice, E.W., Baird, R.B., Eaton, A.D., Eds.; American Water Works Association: Washington, DC, USA, 2017.

49. Uddin Md, G.; Nash, S.; Olbert, A.I. A Review of Water Quality Index Models and Their Use for Assessing Surface Water Quality. Ecol. Indic. 2021, 122, 107218. [CrossRef]

50. Brown, R.M.; McClelland, N.I.; Deininger, R.A.; Tozer, R.G. Water quality index-do we dare? Water Sew. Works 1970, 117, 339-343.

51. Noori, R.; Berndtsson, R.; Hosseinzadeh, M.; Adamowski, J.F.; Abyaneh, M.R. A critical review on the application of the National Sanitation Foundation Water Quality Index. Environ. Pollut. 2019, 244, 575-587. [CrossRef]

52. Singh, P.K.; Saxena, S. Towards developing a river health index. Ecol. Indic. 2018, 85, 999-1011. [CrossRef]

53. The National Environment Policy (NEP). The Ministry of Environment, Forest and Climate Change, Government of India, 2006. Available online: https:/ /ibkp.dbtindia.gov.in/DBT_Content_Test/CMS/Guidelines/20190411103521431_National\%20 Environment\%20Policy,\%202006.pdf (accessed on 3 August 2020).

54. CPHEEO. Advisory on Conservation and Restoration of Water Bodies in Urban Areas. Central Public Health and Environmental Engineering Organization, the Ministry of Urban Development, Government of India; 2013. Available online: http:/ / mohua.gov. in/upload/uploadfiles/files / Advisory\%20on\%20Urban\%20Water\%20Bodies.pdf (accessed on 11 June 2021).

55. Fet, A.M.; Knudson, H. An Approach to Sustainability Management across Systemic Levels: The Capacity-Building in Sustainability and Environmental Management Model (CapSEM-Model). Sustainability 2021, 13, 4910. [CrossRef]

56. CapSeM. Report on Industry Case Presentations. Capsem. Wordpress. 2019. Available online: https:// capsem.files.wordpress. com/2019/03/iitb_industry-case-presentations-report_01mar2019.pdf (accessed on 23 March 2021).

57. Spellman, F.R. The Drinking Water Handbook, 3rd ed.; Routledge: London, UK, 2018.

58. Kadu, V.; Dandwate, V.; Yadav, N.; Bharmal, D. Comparative Study of Two Lakes (Powai and Vihar) In Mumbai, With Respect to Physico-Chemical Parameters and Zooplankton Diversity. Int. J. Sci. Environ. Technol. 2015, 4, 1678-1693.

59. Dodds, W.K.; Whiles, M.R. Freshwater Ecology: Concepts and Environmental Applications of Limnology; Academic Press: San Diego, CA, USA, 2020.

60. Sorensen, D.L.; McCarthy, M.M.; Middlebrooks, E.J.; Porcella, D.B. Suspended and Dissolved Solids Effects on Freshwater Biota: A Review; Report No. EPA600/3-77-042; Corvallis Environmental Research Laboratory, Office of Research and Development, US Environmental Protection Agency: Corvallis, OR, USA, 1977. 
61. Indian Standards Institution. Indian Standards: 2296, Indian Standard Tolerance Limits for Inland Surface Water Subject to Pollution (2nd Revision); Bureau of Indian Standards, Govt. of India: New Delhi, India, 1982.

62. Bhateria, R.; Jain, D. Water quality assessment of lake water: A review. Sustain. Water Resour. Manag. 2016, 2, 161-173. [CrossRef]

63. Vaktania, S. Mumbai Receives Record Monsoon Rains in 2019. India Today, 16 September 2019. Available online: https: //www.indiatoday.in/india/story/mumbai-monsoon-rains-rainfall-record-1599865-2019-09-16 (accessed on 4 June 2021).

64. Carpenter, S.R.; Caraco, N.F.; Correll, D.L.; Howarth, R.W.; Sharpley, A.N.; Smith, V.H. Nonpoint pollution of surface waters with phosphorus and nitrogen. Ecol. Appl. 1998, 8, 559-568. [CrossRef]

65. Vollenweider, R.A. Scientific Fundamentals of the Eutrophication of Lakes and Flowing Waters, with Particular Reference to Nitrogen and Phosphorous as Factors in Eutrophication; Organisation for Economic Co-operation and Development: Paris, France, 1971; Available online: https: / / library.wur.nl/WebQuery/hydrotheek/113312 (accessed on 7 March 2021).

66. Randall, D.J.; Tsui, T.K.N. Ammonia toxicity in fish. Mar. Pollut. Bull. 2002, 45, 17-23. [CrossRef]

67. Downing, J.A.; McCauley, E. The nitrogen: Phosphorus relationship in lakes. Limnol. Oceanogr. 1992, 37, 936-945. [CrossRef]

68. Søndergaard, M.; Jensen, J.P.; Jeppesen, E. Role of sediment and internal loading of phosphorus in shallow lakes. Hydrobiologia 2003, 506-509, 135-145. [CrossRef]

69. USEPA. Recreational Water Quality Criteria. Available online: https://www.epa.gov/sites/production/files/2015-10/ documents/rwqc2012.pdf (accessed on 24 February 2021).

70. Ksoll, W.B.; Ishii, S.; Sadowsky, M.J.; Hicks, R.E. Presence and sources of fecal coliform bacteria in epilithic periphyton communities of Lake Superior. Appl. Environ. Microbiol. 2007, 73, 3771-3778. [CrossRef]

71. Kumar, S.; Kazmi, A.A.; Ghosh, N.C.; Kumar, V.; Rajpal, A. Urban stormwater runoff treatment of Nainital Lake's catchment: An application of ballasted sand flocculation technology. Water Supply 2019, 19, 1017-1025. [CrossRef]

72. Ram, B.; Kumar, M. Correlation appraisal of antibiotic resistance with fecal, metal and microplastic contamination in a tropical Indian river, lakes and sewage. NPJ Clean Water 2020, 3, 1-12. [CrossRef]

73. Starkl, M.; Amerasinghe, P.; Essl, L.; Jampani, M.; Kumar, D.; Asolekar, S.R. Potential of natural treatment technologies for wastewater management in India. J. Water Sanit. Hyg. Dev. 2013, 3, 500-511. [CrossRef]

74. Vymazal, J. Constructed wetlands for wastewater treatment: Five decades of experience. Environ. Sci. Technol. 2011, 45, 61-69. [CrossRef] [PubMed]

75. Kumar, D.; Sharma, S.K.; Asolekar, S.R. Constructed wetlands and other engineered natural treatment systems: India status report. In Natural Water Treatment Systems for Safe and Sustainable Water Supply in the Indian Context: Saph Pani; Wintgens, T., Nattorp, A., Elango, L., Asolekar, S.R., Eds.; IWA Publishing, Gb: London, UK, 2016; pp. 127-142.

76. Kumar, D.; Asolekar, S.R. Experiences with Laboratory and Pilot Scale Constructed Wetlands for Treatment of Sewages and Effluents. In Natural Water Treatment Systems for Safe and Sustainable Water Supply in the Indian Context: Saph Pani; Wintgens, T., Nattorp, A., Elango, L., Asolekar, S.R., Eds.; IWA Publishing, Gb: London, UK, 2016; pp. 149-159.

77. Fowdar, H.S.; Hatt, B.E.; Breen, P.; Cook, P.L.M.; Deletic, A. Designing living walls for greywater treatment. Water Res. 2017, 110, 218-232. [CrossRef] [PubMed]

78. Mujeed, S.; Li, S.; Jabeen, M.; Nassani, A.A.; Askar, S.E.; Zaman, K.; Abro, M.M.Q.; Sriyanto; Jambari, H. Technowomen: Women's autonomy and its impact on environmental quality. Sustainability 2021, 13, 1611. [CrossRef]

79. Zitácuaro-Contreras, I.; Vidal-Álvarez, M.; Hernández y Orduña, M.G.; Zamora-Castro, S.A.; Betanzo-Torres, E.A.; Marín-Muñíz J.L.; Sandoval-Herazo, L.C. Environmental, economic, and social potentialities of ornamental vegetation cultivated in constructed wetlands of Mexico. Sustainability 2021, 13, 6267. [CrossRef]

80. Kakwani, N.S.; Kalbar, P.P. Review of Circular Economy in urban water sector: Challenges and opportunities in India. J. Environ. Manag. 2020, 271, 111010. [CrossRef]

81. iDeCK. Development of Lake Conservation Projects, Karnataka. Infrastructure Development Department, Karnataka. Available online: https: / /idd.karnataka.gov.in/storage/pdf-files/22.Prefea_lake_cons.pdf (accessed on 3 March 2020).

82. Xu, L.; You, H.; Li, D.; Yu, K. Urban Green Spaces, Their Spatial Pattern, and Ecosystem Service Value: The Case of Beijing. Habitat Int. 2016, 56, 84-95. [CrossRef]

83. Simeoni, F.; Cassia, F.; Ugolini, M.M. Understanding the Weak Signals of Demand in a Mature Tourist Destination: The Contribution of a Sustainable Approach. J. Clean. Prod. 2019, 219, 775-785. [CrossRef]

84. Mueller, H.; Hamilton, D.; Doole, G.; Abell, J.; McBride, C. Economic and Ecosystem Costs and Benefits of Alternative Land Use and Management Scenarios in the Lake Rotorua, New Zealand, Catchment. Glob. Environ. Chang. 2019, 54, 102-112. [CrossRef]

85. Fusco Girard, L.; Vecco, M. The "Intrinsic Value" of Cultural Heritage as Driver for Circular Human-Centered Adaptive Reuse. Sustainability 2021, 13, 3231. [CrossRef]

86. Mueller, H.; Hamilton, D.P.; Doole, G.J. Response Lags and Environmental Dynamics of Restoration Efforts for Lake Rotorua, New Zealand. Environ. Res. Lett. 2015, 10, 074003. [CrossRef] 